\title{
FOREST PRODUCTIVITY DECLINE CAUSED BY SUCCESSIONAL PALUDIFICATION OF BOREAL SOILS
}

\author{
Martin Simard, ${ }^{1,2,3}$ Nicolas Lecomte,${ }^{1,4}$ Yves Bergeron, ${ }^{1}$ Pierre Y. Bernier, ${ }^{2}$ and David Paré ${ }^{2}$ \\ ${ }^{1}$ NSERC-UQAT-UQAM Industrial Chair in Sustainable Forest Management, Université du Québec en Abitibi-Témiscamingue, \\ 445 boul. de l'Université, Rouyn-Noranda, Québec J9X4E5 Canada, and Centre d'Études sur la Forêt (CEF), \\ Université du Québec à Montréal, CP 8888, Succursale Centre-ville, Montréal, Québec H3C 3P8 Canada \\ ${ }^{2}$ Natural Resources Canada, Canadian Forest Service, Laurentian Forestry Centre, 1055 du PEPS, CP 10380, Succursale Sainte-Foy, \\ Québec G1V 4C7 Canada
}

\begin{abstract}
Long-term forest productivity decline in boreal forests has been extensively studied in the last decades, yet its causes are still unclear. Soil conditions associated with soil organic matter accumulation are thought to be responsible for site productivity decline. The objectives of this study were to determine if paludification of boreal soils resulted in reduced forest productivity, and to identify changes in the physical and chemical properties of soils associated with reduction in productivity. We used a chronosequence of 23 black spruce stands ranging in postfire age from 50 to 2350 years and calculated three different stand productivity indices, including site index. We assessed changes in forest productivity with time using two complementary approaches: (1) by comparing productivity among the chronosequence stands and (2) by comparing the productivity of successive cohorts of trees within the same stands to determine the influence of time independently of other site factors.

Charcoal stratigraphy indicates that the forest stands differ in their fire history and originated either from high- or low-severity soil burns. Both chronosequence and cohort approaches demonstrate declines in black spruce productivity of $50-80 \%$ with increased paludification, particularly during the first centuries after fire. Paludification alters bryophyte abundance and succession, increases soil moisture, reduces soil temperature and nutrient availability, and alters the vertical distribution of roots. Low-severity soil burns significantly accelerate rates of paludification and productivity decline compared with high-severity fires and ultimately reduce nutrient content in black spruce needles. The two combined approaches indicate that paludification can be driven by forest succession only, independently of site factors such as position on slope. This successional paludification contrasts with edaphic paludification, where topography and drainage primarily control the extent and rate of paludification. At the landscape scale, the fire regime (frequency and severity) controls paludification and forest productivity through its effect on soil organic layers. Implications for global carbon budgets and sustainable forestry are discussed.
\end{abstract}

Key words: black spruce; boreal forest; chronosequence; fire severity; long-term forest productivity; paleoecology; paludification; Picea mariana; Pleurozium schreberi; Quebec, Canada; site index; soil organic matter; Sphagnum spp.

\section{INTRODUCTION}

Age-related decline in forest productivity has received increasing attention in the last decades because of its potential for affecting both global carbon budgets and sustainable forest management (Dyck et al. 1994, Ryan et al. 1997, 2004, Zaehle et al. 2006). In northern forest ecosystems, one cause of productivity decline is the accumulation of a thick organic layer that contributes to soil cooling and restricts nutrient mineralization and

Manuscript received 27 October 2006; revised 12 February 2007; accepted 23 February 2007. Corresponding Editor: D. McKenzie.

${ }^{3}$ Present address: University of Wisconsin, Department of Zoology, Birge Hall, 430 Lincoln Drive, Madison, Wisconsin 53706 USA. E-mail: simard@wisc.edu

${ }^{4}$ Present address: President, Valeur Nature, 2709 Boulevard McDuff, Local F, Valcanton, Québec J0Z 1H0 Canada. uptake by plants (Gower et al. 1996, Murty et al. 1996, Prescott et al. 2000). The magnitude of this decline has been poorly documented, especially in forest ecosystems that accumulate large amounts of soil organic matter (SOM) over long periods of time. This work will quantify changes in forest productivity with time since fire in an ecosystem prone to paludification, and identify physical and chemical properties of soils that are associated with productivity decline. This in turn will help predict changes in forest productivity as affected by natural and anthropogenic disturbances.

In many boreal ecosystems, SOM accumulation is prevalent because low soil temperatures favor plant growth over decomposition in the soil (Swanson et al. 2000). Because SOM contains high concentrations of nutrients that are bound to complex organic molecules (Prescott et al. 2000), forest fires act as important drivers 
of northern forest productivity by releasing organically bound nutrients and stimulating nutrient cycling (MacLean 1983, Wardle et al. 1997, 2003, Smithwick et al. 2005). Additionally, SOM consumption creates microsites necessary for tree regeneration (Charron and Greene 2002). Soil burn severity, i.e., the depth of SOM layer burned, therefore controls postfire site productivity (Viereck 1983, Johnstone and Chapin 2006). The excessive accumulation of SOM can sometimes lead to the formation of peatlands, a process called paludification (Payette and Rochefort 2001). The most common and most studied type of paludification occurs in wet topographic lows, where high water table promotes the growth of peat-forming plants (e.g., sedges and Sphagnum species) (Heinselman 1970, Khury et al. 1993, Payette 2001). A less-studied type of paludification is that of well-drained soils, where peat-forming mosses accumulate directly on mesic soils. This type of paludification is primarily related to forest succession between fire events, independent of site topography or drainage. These two types of paludification can also be called edaphic and successional, a terminology that highlights the contrasting factors controlling water table levels and driving paludification, i.e., topography and SOM accumulation due to succession. In most landscapes, however, both types of paludification are confounded, with slope typically modulating the rate of successional paludification.

Successional paludification has been described at different stages of development in Alaska (Heilman 1966, Viereck 1970, Van Cleve and Viereck 1981, Van Cleve et al. 1983), British Columbia (Asada et al. 2004), Labrador (Foster 1985), and in the Clay Belt of Ontario and Quebec (Fenton et al. 2005, Lecomte et al. 2006b). In Alaska, chronosequence studies have described accumulation of SOM in black spruce stands accompanied by decreased soil temperatures resulting in permafrost, increased soil moisture, decreased nutrient cycling, and decreased aboveground biomass (Van Cleve and Viereck 1981, Van Cleve et al. 1983, Viereck 1983). This pioneering work by Van Cleve et al. $(1983,1991)$ has demonstrated the importance of using multiple research approaches to study the different factors (soil temperature and moisture, nutrient pools and fluxes, etc.) driving forest productivity in ecosystems prone to paludification. In the Clay Belt of Ontario and Quebec, successional paludification has been shown to occur between fire events without the development of permafrost and to be associated with an increase in the abundance of Sphagnum spp., high water tables, and low tree biomass (Harper et al. 2003, Fenton et al. 2005, Lecomte et al. 2005, Fenton and Bergeron 2006, Lecomte et al. 2006a, $b$ ). In this ecosystem low-severity soil burns (i.e., ground fires that only partially consume the organic layer) have been shown to promote paludification, thereby creating alternative postfire successional pathways, and altering stand structure and ecosystem biomass partitioning (Lecomte et al. 2005, 2006a, b).

In this study, our objectives were to: (1) determine if successional paludification of black spruce (Picea mariana) stands leads to reduced forest productivity in the Clay Belt of northwestern Quebec, and (2) identify changes in the physical and chemical properties of soils associated with a reduction in productivity. Following previous studies in Alaskan forests, we used multiple approaches to reach these objectives. We used a chronosequence of 23 black spruce stands ranging in postfire age from 50 to 2350 years and calculated three different stand productivity indices, including site index. We assessed change in forest productivity over time using two complementary approaches: (1) by comparing productivity among the chronosequence stands, and (2) by comparing the productivity of successive cohorts of trees within the same stands. Black spruce productivity has been shown to be negatively related to SOM layer depth along toposequences (i.e., from peatland center to edge [Heinselman 1963]), but relationships within chronosequences have remained more elusive. In most chronosequence studies, the relative contribution of toposequence and chronosequence is difficult to assess because of approximate dating of postfire stand age and the mostly unverified assumption that all chronosequence stands shared similar initial conditions. In this study, postfire stand age was accurately determined using tree ring and radiocarbon dating, and stand history was carefully reconstructed at each site using paleoecological analysis of charcoal fragments and plant macroremains to ensure that all stands established under similar postfire conditions (fire severity, tree and understory composition, drainage, etc.).

\section{Regional Setting}

The study area $\left(49^{\circ} 00^{\prime}-50^{\circ} 00^{\prime} \mathrm{N} ; 78^{\circ} 30^{\prime}-79^{\circ} 30^{\prime} \mathrm{W}\right)$ is located in the boreal zone of western Quebec (Canada), some $200 \mathrm{~km}$ south of James Bay. This region of the Precambrian Shield is covered by thick deposits of varved clays left by proglacial Lake Barlow-Ojibway, forming the physiographic unit known today as the Clay Belt, which covers a large part of the Hudson Bay lowlands (Veillette 1994; see Plate 1). Southward glacial surges around 8200 years BP incorporated gravels in the glaciolacustrine clays, resulting in a relatively compact surficial deposit called the Cochrane Till (Veillette 1994). Topography is generally flat (mean altitude is $250 \mathrm{~m}$ above sea level) with some scattered, rocky outcrops. About half of the area is overlaid by organic deposits $>60 \mathrm{~cm}$ thick, lying mostly on clay deposits. The most common soil types on well-drained clay deposits are Luvisols (Soil Classification Working Group 1998). The climate is subpolar, subhumid continental (Robitaille and Saucier 1998), with a mean annual temperature of $-0.7^{\circ} \mathrm{C}$ (mean temperatures of January and July are $-20.0^{\circ} \mathrm{C}$ and $16.1^{\circ} \mathrm{C}$, respectively) and annual precipita- 


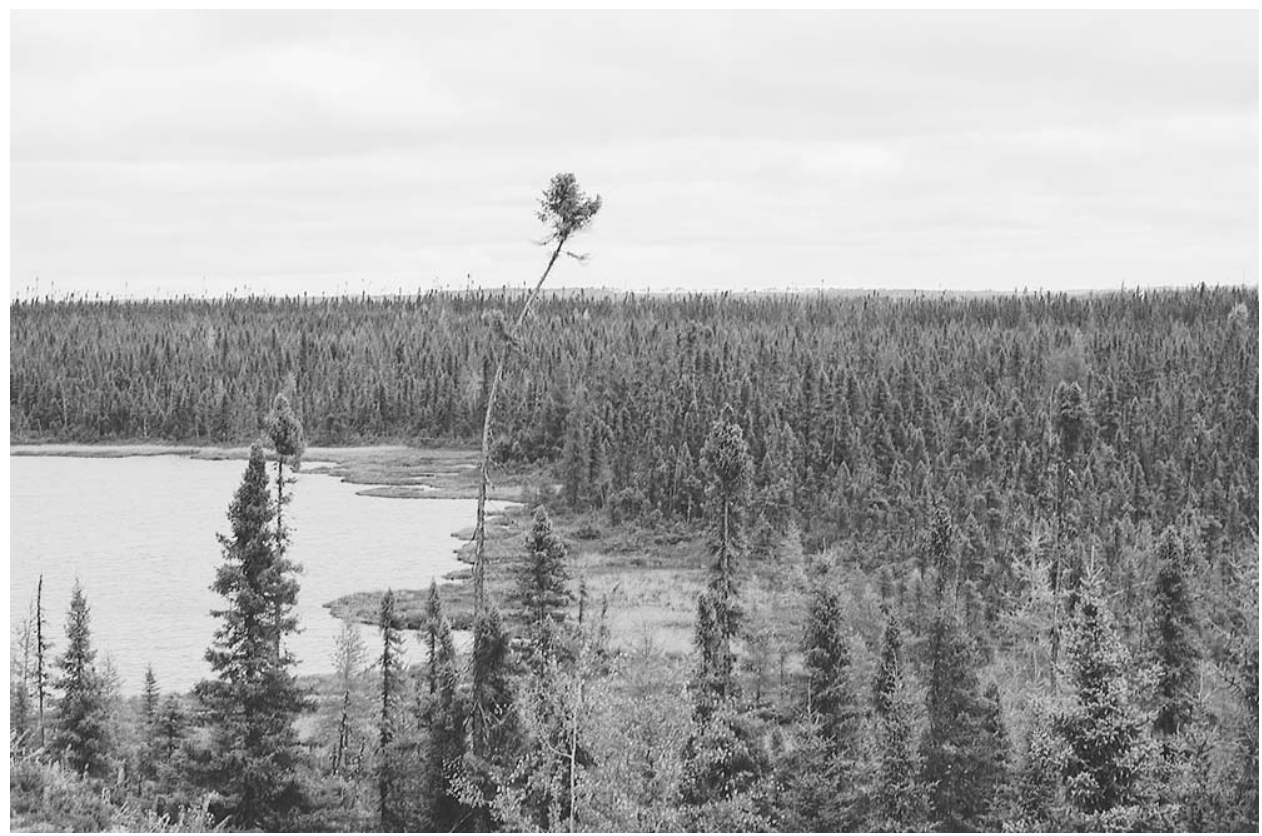

Plate 1. The flat topography, compact surficial deposits, and cold climate of the Hudson Bay lowlands promote paludification, i.e., the accumulation of deep peat layers, across the black-spruce-dominated landscape. Photo credit: M. Simard.

tion of $905 \mathrm{~mm}, 35 \%$ of which falls during the growing season (Matagami weather station, $49^{\circ} 46^{\prime} \mathrm{N}, 77^{\circ} 49^{\prime} \mathrm{W}$ [Environment Canada 2006]). The heat sum (degreedays $>5^{\circ} \mathrm{C}$ ) reaches 1170 degree-days, and growingseason frosts are frequent throughout the area.

The region is dominated by black spruce (Picea mariana (Mill.) B.S.P.) - moss forests that vary in density and height. Occasional stands of jack pine (Pinus banksiana Lamb.) and aspen (Populus tremuloides Michx.) occur and are often mixed with black spruce (Gauthier et al. 2000). Tamarack (Larix laricina (Du Roi) K. Koch), balsam fir (Abies balsamea (L.) Mill.), and paper birch (Betula papyrifera Marsh.) are a minor component of the forest matrix. The understory is mainly composed of ericoid shrubs (Vaccinium spp., Rhododendron groenlandicum, Kalmia angustifolia), and the ground layer is dominated by feathermosses (Pleurozium schreberi, Ptilium crista-castrensis, and Hylocomium splendens) or peat mosses (Sphagnum spp.). The fire cycle was estimated to be $\sim 100$ years before 1850,135 years between 1850 and 1920, and $\sim 400$ years since 1920 (Bergeron et al. 2004). Intensive logging on the most productive sites began in the 1970s and has profoundly marked the landscape. Most harvesting is done during the winter, using careful logging techniques that aim at protecting soils and advance growth. Although the area is under active fire suppression, there is no evidence that it has significantly affected the fire cycle because large fires, which are responsible for most of the annual area burned, usually cannot be controlled. On the other hand, field crews are very effective at putting out smoldering combustion of SOM once fire spread has ceased. The spruce budworm (Choristoneura fumiferana (Clem.)), which is near its northernmost range limit, has a negligible impact in the study area, according to historical patterns of budworm defoliation (Gray et al. 2000) and tree ring reconstructions (M. Simard, N. Lecomte, and Y. Bergeron, unpublished data).

\section{Methods}

We studied paludification in a chronosequence of stands using a hierarchical approach in which 23 stands were sampled for stand productivity, SOM accumulation, and ground cover composition. A subset of 11 stands was further used for soil analyses, root system excavation, and Sphagnum succession, 6 of which were finally sampled for leaf nutrient analyses.

\section{Site selection and dating}

Chronosequence stands were preselected using a stand initiation map that was developed for the study area (Bergeron et al. 2004). Within this map, all black sprucedominated stands growing on fine-textured soils and gentle slope, without signs of anthropogenic disturbance, and $<2 \mathrm{~km}$ from a road, were visited. In all, 23 stands were selected (Table 1), including three pairs of stands each originating from the same fire (three fire years: 1907, 1948, and 1949), but with contrasting stem density. A $10 \times 10 \mathrm{~m}$ quadrat was positioned in a representative portion of each stand for detailed dendroecological analysis. In each quadrat, the diameter at breast height (dbh; $1.3 \mathrm{~m}$ ) of each stem $>2 \mathrm{~m}$ in height (dead and live) was measured, and stems buried under the organic layer were exhumed and measured. Dead 
TABLE 1. Characteristics of stands forming the chronosequence.

\begin{tabular}{|c|c|c|c|c|c|c|c|}
\hline \multirow[b]{2}{*}{ Stand $\dagger$} & \multirow[b]{2}{*}{$\begin{array}{c}\text { Fire } \\
\text { severity }\end{array}$} & \multirow[b]{2}{*}{$\begin{array}{l}\text { ROM layer } \\
\quad(\mathrm{cm}) \S\end{array}$} & \multicolumn{4}{|c|}{ Relative basal area (\%)\| } & \multirow{2}{*}{$\begin{array}{l}\text { Number of } \\
\text { trees dated } \\
\text { (live/dead) }\end{array}$} \\
\hline & & & $\begin{array}{l}\text { Black } \\
\text { spruce }\end{array}$ & $\begin{array}{l}\text { Jack } \\
\text { pine }\end{array}$ & $\begin{array}{l}\text { Balsam } \\
\text { fir }\end{array}$ & $\begin{array}{c}\text { Eastern } \\
\text { larch }\end{array}$ & \\
\hline HI-52ब & high & 1.4 & 94 & 0 & 0 & 6 & $25 / 0$ \\
\hline HI-539 & high & 2.5 & 96 & 0 & 4 & 0 & $62 / 27$ \\
\hline HI-76 & high & 1.5 & 98 & 2 & 0 & 0 & $35 / 12$ \\
\hline HI-85 & high & 1.9 & 100 & 0 & 0 & 0 & $40 / 40$ \\
\hline HI-94ণ & high & 2.5 & 100 & 0 & 0 & 0 & $62 / 60$ \\
\hline HI-95 & high & 1.1 & 100 & 0 & 0 & 0 & $20 / 6$ \\
\hline HI-126 & high & 2.0 & 98 & 0 & 0 & 2 & $55 / 16$ \\
\hline HI-128 & high & 2.0 & 100 & 0 & 0 & 0 & $71 / 5$ \\
\hline HI-174 & high & 1.4 & 97 & 0 & 3 & 0 & $27 / 3$ \\
\hline HI-184 & high & 1.3 & 93 & 0 & 7 & 0 & $36 / 10$ \\
\hline HI-365 & high & 2.0 & 72 & 0 & 28 & 0 & $31 / 25$ \\
\hline HI-710 & high & 3.2 & 100 & 0 & 0 & 0 & $15 / 1$ \\
\hline HI-790 & high & 1.7 & 94 & 0 & 6 & 0 & $16 / 1$ \\
\hline HI-1225 & high & 1.5 & 86 & 0 & 14 & 0 & $15 / 1$ \\
\hline HI-1585 & high & 2.7 & 100 & 0 & 0 & 0 & $27 / 0$ \\
\hline HI-2355 & high & 3.2 & 100 & 0 & 0 & 0 & $14 / 0$ \\
\hline LO-38 & low & 12.0 & 100 & 0 & 0 & 0 & $25 / 0$ \\
\hline LO-52ণ & low & 13.0 & 100 & 0 & 0 & 0 & $30 / 0$ \\
\hline LO-53 & low & 7.3 & 100 & 0 & 0 & 0 & $90 / 7$ \\
\hline LO-94" & low & 16.2 & 98 & 0 & 0 & 2 & $82 / 7$ \\
\hline LO-143 & low & 7.9 & 97 & 0 & 3 & 0 & $25 / 8$ \\
\hline LO-151 & low & 17.3 & 98 & 0 & 0 & 2 & $25 / 12$ \\
\hline LO-169 & low & 8.4 & 100 & 0 & 0 & 0 & $23 / 5$ \\
\hline
\end{tabular}

$\dagger$ Stand identification represents soil burn severity $(\mathrm{HI}=$ high severity; $\mathrm{LO}=$ low severity) and postfire age. Stands in boldface type were sampled for soil analyses and root system excavation.

\$ Fire severity determined from thickness of the residual organic matter layer (see Methods).

$\S$ Thickness of the residual organic matter (ROM layer), i.e., the organic matter that was not burned by the last fire, located between the mineral horizon and the uppermost charcoal layer.

|| Relative basal area of major overstory species (live and dead trees; all buried stems were exhumed).

- Stand age determined from tree ring analysis. Stands where the postfire cohort of trees was not found were given a minimum age and were radiocarbon dated.

\# Radiocarbon dates from carbonized plant macroremains of the uppermost charcoal layer in soils (see Methods). 2005).

$\dagger$ Radiocarbon dates from organic matter located immediately above the uppermost charcoal layer in soils (from Cyr et al. H.

\$ Slope measured on $100 \mathrm{~m}$.

$\S \S$ Mineral soil texture was determined with the Bouyoucos hydrometer method (McKeague 1976) from two samples of the C horizon (upper $\mathrm{C}$ horizon, and $1 \mathrm{~m}$ below the B/C interface). Nomenclature follows the Canadian System of Soil Classification (Soil Classification Working Group 1998). Key: HC= Heavy Clay; C=Clay.

ฯ Paired stands that originated from the same fire, had different soil burn severity, and were sampled for leaf nutrient analyses.

and buried stems were identified to species level using macroscopic anatomical features of tree rings when bark was missing (Panshin and de Zeeuw 1980). At each site, ground cover of major moss and lichen taxa was estimated in $101-\mathrm{m}^{2}$ plots located every $2 \mathrm{~m}$ along two randomly placed $10-\mathrm{m}$ transects.

Postfire stand age was obtained by dating cross sections sampled at the base of live and dead dominant trees. Cross sections were finely sanded until xylem cells were visible and crossdated using a frost-ring chronology under $40 \times$ magnification (M. Simard, unpublished data). A stand was attributed a given fire year when at least five trees showing rapid initial growth were dated within the same 10-year period. In some stands, all trees were dated in the $100-\mathrm{m}^{2}$ quadrat. In stands where no fire scars were found, where age structure showed no synchronous tree establishment (Appendix A), or where dominant trees were older than 200 years and had slow initial growth likely caused by suppression, samples of carbonized plant remains found in the uppermost charcoal layer of the organic layer were sent to IsoTrace Laboratory (Toronto, Canada) for AMS (Accelerator Mass Spectrometry) radiocarbon dating (see below for paleoecological methods). Radiocarbon years were calibrated in calendar years using INTCAL98 (Stuiver and Reimer 1993).

\section{Charcoal and plant macrofossil analysis}

To determine the fire and vegetation history and verify if initial conditions were similar in all stands forming the chronosequence, paleoecological analysis was conducted on soil organic layer samples. Two to three $10 \times 10 \mathrm{~cm}$ monoliths of the soil organic layer were sampled down to the mineral soil at each site (total sample size $n=55$ ). The monoliths were frozen and sliced in $1-\mathrm{cm}$ sections. Subsamples of $50 \mathrm{~cm}^{3}$ were defloculated in $2 \% \mathrm{NaOH}$ for $24 \mathrm{~h}$ at $60^{\circ} \mathrm{C}$, sieved through 2-mm, 1-mm, and $0.25-\mathrm{mm}$ mesh using a gentle water spray, and bleached in a $10-20 \% \mathrm{HCl}$ solution. The macroremains were identified under a dissecting 
TABle 1. Extended.

\begin{tabular}{|c|c|c|c|c|}
\hline \multicolumn{3}{|c|}{ Stand age (years) } & \multirow[b]{2}{*}{$\begin{array}{l}\text { Slope } \\
(\%)+t\end{array}$} & \multirow[b]{2}{*}{$\begin{array}{c}\text { Mineral } \\
\text { soil } \\
\text { texture } \S\end{array}$} \\
\hline $\begin{array}{l}\text { Tree ring } \\
\text { dating }\end{array}$ & $\begin{array}{l}\text { Calibrated } \\
{ }_{14} \mathrm{C} \text { age } \\
\text { (charcoal)\# }\end{array}$ & $\begin{array}{l}\text { Calibrated } \\
{ }^{14} \mathrm{C} \text { age } \\
\text { (humus) } \dagger \dagger\end{array}$ & & \\
\hline 52 & & & 4.6 & $\mathrm{HC}$ \\
\hline 53 & & & 3.0 & $\mathrm{HC}$ \\
\hline 76 & & & 1.5 & $\mathrm{HC}$ \\
\hline 85 & & & 1.1 & $\mathrm{HC}$ \\
\hline 94 & & & 1.6 & $\mathrm{C}$ \\
\hline 95 & & & 2.1 & $\mathrm{HC}$ \\
\hline 126 & & & 1.9 & $\mathrm{HC}$ \\
\hline 128 & & & 0.7 & $\mathrm{HC}$ \\
\hline 174 & & & 1.8 & $\mathrm{HC}$ \\
\hline 184 & & & 2.4 & $\mathrm{HC}$ \\
\hline$>222$ & 365 & & 1.7 & C \\
\hline$>280$ & 710 & 555 & 0.8 & $\mathrm{HC}$ \\
\hline$>217$ & 790 & & 2.1 & $\mathrm{HC}$ \\
\hline$>215$ & 1225 & & 1.5 & $\mathrm{HC}$ \\
\hline$>286$ & 1585 & 705 & 1.1 & $\mathrm{HC}$ \\
\hline$>353$ & 2355 & & 0.8 & $\mathrm{HC}$ \\
\hline 38 & & & 2.0 & C \\
\hline 52 & & & 1.6 & $\mathrm{HC}$ \\
\hline 53 & & & 1.2 & $\mathrm{C}$ \\
\hline 94 & & & 1.7 & $\mathrm{HC}$ \\
\hline 143 & & & 1.3 & $\mathrm{HC}$ \\
\hline 151 & & & 0.9 & $\mathrm{C}$ \\
\hline 169 & & & 0.5 & C \\
\hline
\end{tabular}

microscope at $40 \times$ magnification. To determine SOM layer depth in the monoliths, we needed to clearly identify the mineral soil-organic matter interface, which was sometimes blurred by soil mixing. This threshold was established where the mineral fraction represented $\sim 25 \%$ of the sample. Plant macroremains (leaf, cone scales, seeds, etc.) were identified to species, genus, or family level depending on the presence of distinctive features and extent of decomposition. We used the macrofossil record from the first $5 \mathrm{~cm}$ of organic matter overlying the charcoal layer ("early macrofossil record") to assess postfire vegetation. Charcoal fragments were extracted, dried, and weighed. The thickness of the residual organic matter layer (ROM; i.e., the organic matter below the uppermost charcoal layer that was not consumed by the last fire) was calculated for each monolith as the number of $1-\mathrm{cm}$ sections above the mineral soil but below the most recent (uppermost) charcoal horizon.

The ROM layer thickness was also measured in several soil pits and trenches in the younger stands $(<200$ years) to supplement the low number of highresolution monoliths. In older stands, strong humification of lower organic horizons and high water table prevented unequivocal identification of the mineralorganic interface in the field. At each site, 15 soil pits (25 $\times 25 \mathrm{~cm}$ ) were dug to the mineral soil every $2 \mathrm{~m}$ along three randomly placed $10-\mathrm{m}$ transects, and two $2.25 \mathrm{~m}$ long trenches were dug. For each soil pit (every $15 \mathrm{~cm}$ along the trenches), the uppermost charcoal horizon was located and the depth of the ROM (mineral soil to charcoal) and of the organic matter accumulated since the last fire (charcoal to surface) were measured.

Soil burn severity of the last fire was estimated at each of the 23 stands from the average thickness of the ROM layer using data from the monoliths, soil pits, and trenches. Although most stands had a single charcoal layer overlying the mineral soil, seven stands had a thick $(7-17 \mathrm{~cm})$ layer of well-decomposed ROM located below the topmost charcoal layer with one or several additional charcoal horizons (Table 1, Appendix B). This suggested contrasting fire histories, i.e., stands originating from fires of high vs. low severity, as shown by the bimodal frequency distribution of the ROM layer thickness (Appendix B). The stands were thus classified as originating either from a high-severity (HS; $n=16$ stands) or low-severity (LS; $n=7$ stands) fire, based on the average thickness of the ROM layer (Table 1, Fig. 1). In this study, fire severity exclusively relates to soil burn severity, as dendroecological analyses suggest that the aboveground severity (tree mortality) was consistently high (i.e., no survivors; Appendix A).

\section{Stand productivity indices}

We used three different indices of forest productivity in this study: one based on tree height (site index, i.e., observed tree height at 50 years), one based on tree radial growth (5-year basal area increment [BAI]), and a stand-level index, i.e., stand biomass. Each of these indices expresses productivity in a different way (e.g., potential productivity with site index vs. realized productivity with stand biomass vs. short-term productivity with 5-year BAI). Site index and 5-year BAI were calculated using three trees from each height cohort (1-3 cohorts per stand), whereas stand biomass was calculated from the dbh of living trees in the $100-\mathrm{m}^{2}$ quadrat, using allometric equations developed for black spruce (Ouellet 1983). During the summers of 1999 to 2001, stem analyses were performed on three black spruce trees of the dominant cohort (hereafter called first cohort) at each stand. Cross sections were sampled at $0,0.4$, and $1 \mathrm{~m}$, and every $1 \mathrm{~m}$ thereafter. Additional stem analyses were performed on three stems of the second and third height cohort, when present. We selected the second and third cohorts based on the vertical distribution of trees in the canopy and on the $\mathrm{dbh}$ structure of the stands; the cohorts had to be separated by a vertical distance of at least $5 \mathrm{~m}$. To avoid sampling suppressed trees, all sampled trees $(n=$ 147) had to be growing in full light. All trees also had to be free of any connection with a living genet. Two measures of SOM layer depth were taken in opposite directions at $10 \mathrm{~cm}$ from each tree base. Cross sections were processed and crossdated as above (see Methods: Site selection and dating). The lowermost section of each tree was then measured on two (dominant cohort) or one (second and third cohort) radii with a Velmex micrometer (precision of $0.01 \mathrm{~mm}$ ) under $40 \times$ magnification (Velmex Incorporated, Bloomfield, New York, 
High-severity fire, TSF $=94 \mathrm{yr}$
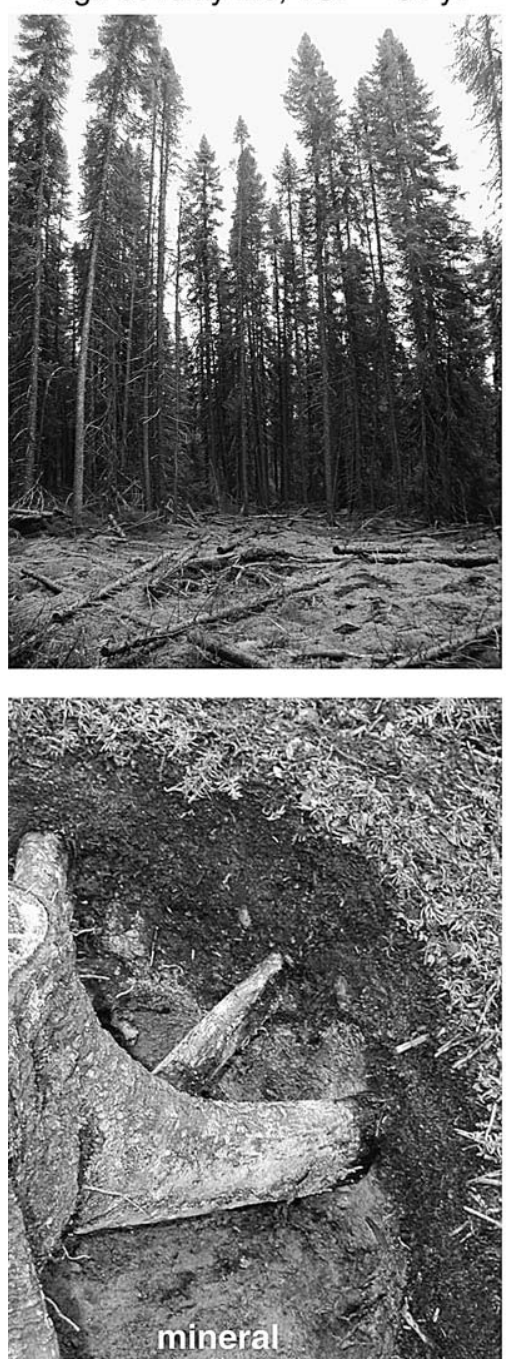

High-severity fire, $\mathrm{TSF}=710 \mathrm{yr}$
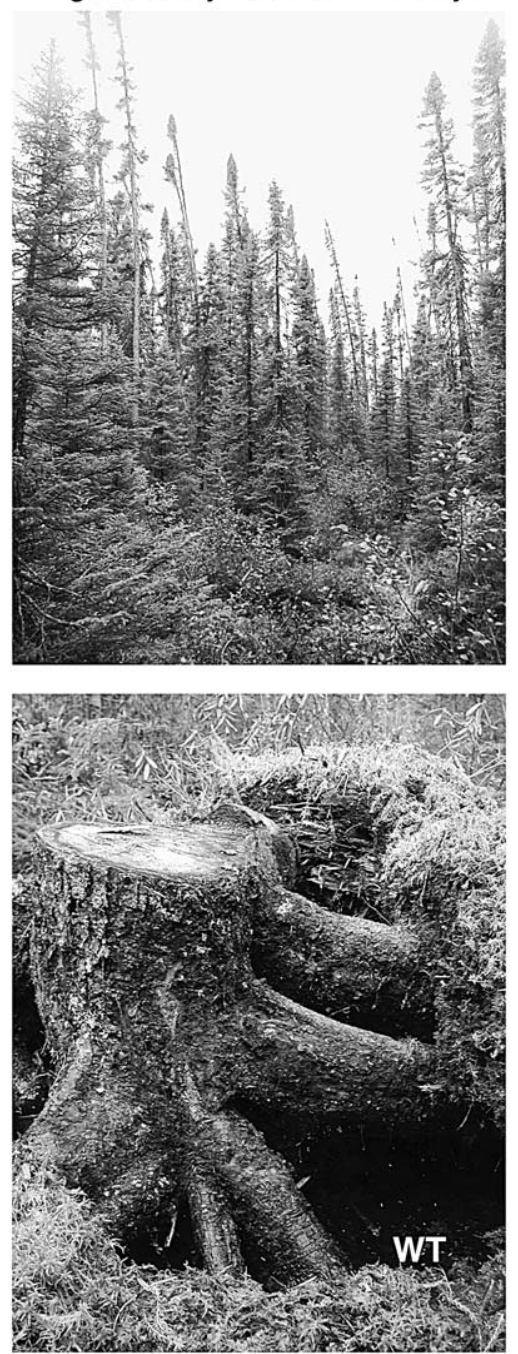

Low-severity fire, $\mathrm{TSF}=94 \mathrm{yr}$
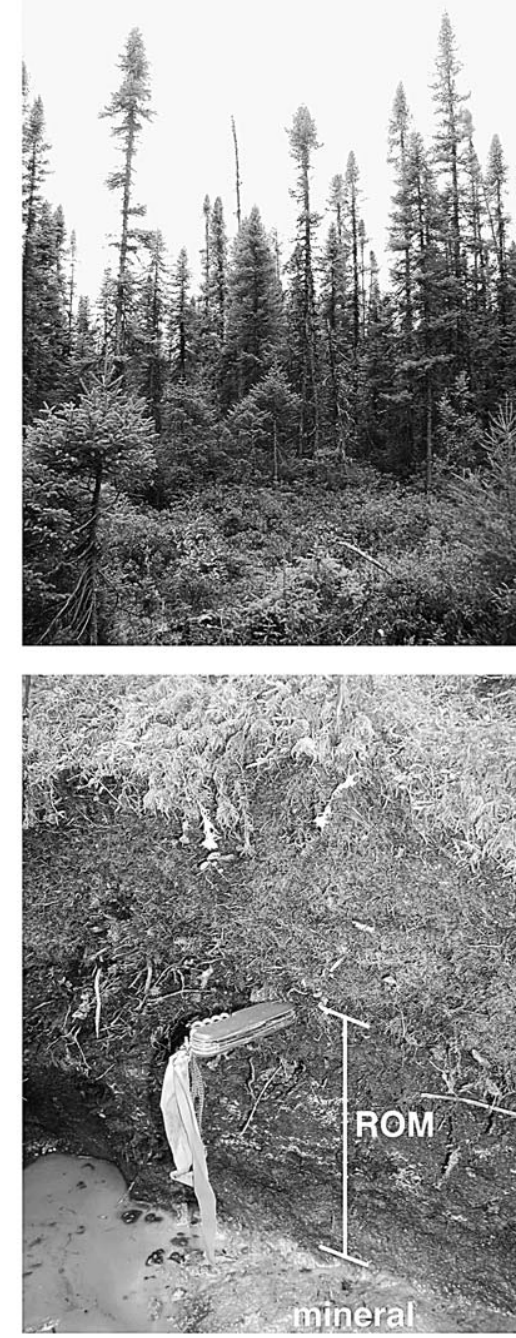

FIG. 1. In the Hudson Bay Lowlands, black spruce (Picea mariana) productivity is driven by time since last fire and soil burn severity, which together control soil organic layer depth. (Left) After high-severity soil burns, dense productive stands establish primarily on mineral soils and have a ground layer dominated by feathermosses. (Center) Old paludified stands have deep organic soils where most of the roots are located, high water tables (WT), and open and multistoried canopies; they are dominated by Sphagnum spp. (Right) Young stands originating from low-severity soil burns are characterized by residual organic matter (ROM) that was not consumed by the fire and are structurally similar to old paludified stands originating from high-severity soil burns. Stands shown are HI-94 (left), HI-710 (center), and LO-94 (right). Photo credit: M. Simard.

USA). The dating and homogeneity of tree ring series were validated with the program COFECHA (Holmes 1983).

For each tree, we calculated site index as the height grown in 50 years of free (i.e., unsuppressed) growth, using stem height increment patterns to define major inflexions in the age-height growth curve indicating growth release (Curtis 1964). We also calculated the 5-year (1995-1999) BAI, which standardizes for the agerelated decline in radial growth that is caused by the increasing area of cambium, and is considered to represent unbiased growth trends (LeBlanc 1990).

Change in stand productivity with time was assessed with a mixed linear model that tested the effects of time since fire (TSF; or stand age), soil burn severity (SEV: HS vs. LS), and cohort $(\mathrm{COH}$; i.e., the change in productivity from one cohort of trees to the next within the same stand; this effect was not tested for stand biomass), with stand as a random effect (Proc MIXED; SAS Institute 2000). When necessary, we log-transformed variables to linearize them or to meet the assumptions of normality and homogeneity of the residuals. Variables and interactions that were not significant $(\alpha=0.05)$ were removed. Time since fire was calculated as the time elapsed between the fire event and growth release for site index, between fire and 1995 for 5-year BAI, and between fire and date of sampling for stand biomass. 


\section{Soil sampling and rooting depth}

Limited sampling time necessitated that we select a subsample of stands for soil and rooting depth measurements. Eight stands established after HS fires and three stands established after LS fires were chosen (Table 1); three of the eight HS stands were the same-age counterpart of the three LS stands and were sampled to specifically test the effect of fire severity independently of stand age (see Methods: Stand selection and dating).

At each stand, we measured the rooting profile of the black spruce trees that were sampled for stem analyses (see Methods: Stand productivity indices). All root systems were excavated, drawn to scale, and the circumference, thickness, and depth of each root $>1 \mathrm{~cm}$ in diameter was measured at a reference distance of $30 \mathrm{~cm}$ from stump center. Depths of mineral soil, charcoal horizons, and organic layer surface were also measured along the $30 \mathrm{~cm}$ radius circle so that rooting depth could be related to soil horizons.

We measured soil temperature and water table depth during one visit in each stand. Measurements were taken every $1 \mathrm{~m}$ along a randomly located $20-\mathrm{m}$ transect. Soil temperature was measured with a thermocouple fixed on a wooden rod, at a depth of $5 \mathrm{~cm}, 10 \mathrm{~cm}$, and every $10 \mathrm{~cm}$ thereafter until the mineral soil was reached. Soil temperature sampling took place in the late summer of 2003 (mid-August) and 2004 (mid-September), during a time of the year where the soil thermal profile is the most developed. Soil temperature and water table depth were not measured in stand HI-184 in 2004 because it was harvested the previous winter, and soil temperature was not measured in the paired stands HI-94 and LO-94 in 2004 due to equipment failure.

Major bryophyte taxa were identified to the genus level in the full chronosequence (23 stands; see Site selection and dating). We also resampled bryophytes for identification at the species level to examine possible successional trends in composition. We identified bryophyte species at each sampling point $(n=20)$ in a $20 \mathrm{~cm}$ diameter circular plot in 2004 (except in the logged stand HI-184) and brought Sphagnum samples back to the laboratory for definitive identification using microscopic characteristics.

The organic layer was sampled at five locations randomly chosen along the $20-\mathrm{m}$ transects. At each location, a $10 \times 10 \times 5 \mathrm{~cm}$ thick sample was collected at $5 \mathrm{~cm}$ under the organic layer surface ("upper organic horizon"), just above the most recent charcoal layer ("lower organic horizon"); a sample of mineral soil was also collected. In the three LS stands that had postfire ROM, an additional sample was taken just below the last charcoal horizon ("residual organic matter horizon"). SOM samples were carefully retrieved to avoid change in volume, promptly placed in a cooler, and brought to the laboratory for analysis. Water content, density, level of humification (von Post pressing method and sodium pyrophosphate colorimetric method [Parent and Caron 1993]), $\mathrm{pH}$ (fresh sample, in water), and loss on ignition $\left(550^{\circ} \mathrm{C}\right)$ of organic samples were determined. Exchangeable cations were extracted from mineral and organic soil samples using an unbuffered $0.1 \mathrm{~mol} / \mathrm{L} \mathrm{BaCl}_{2}$ solution and determined by atomic absorption (Hendershot et al. 1993). The Effective Cationic Exchange Capacity (ECEC) was determined as the sum of exchangeable cations ( $\mathrm{Na}, \mathrm{K}, \mathrm{Ca}, \mathrm{Mg}, \mathrm{Mn}, \mathrm{Fe}$, and $\mathrm{Al}$ ), and base saturation as the contribution of $\mathrm{Ca}, \mathrm{Mg}$, and $\mathrm{K}$ on the ECEC. Total carbon and total nitrogen of both organic and mineral samples were measured using an automated LECO analyzer (model CNS-2000, LECO Australia Pty. Limited, Baulkham Hills, New South Wales, Australia). Because peat density varies with humification, and to compare mineral and organic horizons, the ECEC and $\mathrm{C}$ and $\mathrm{N}$ concentrations were converted from a mass basis to a volume basis using the measured density of the organic matter samples and an average density of $1.14 \mathrm{~g} / \mathrm{cm}^{3}$ for the fine-textured mineral soil (Brais 2001).

The low number of available LS stands $(n=3)$ in this short chronosequence prohibited the use of regression analysis. All statistical analyses (for rooting depth, soil temperature, water table depth, and soil chemical and physical properties) were therefore performed in two separate tests. We first tested the effect of time since fire (TSF) using only the $8 \mathrm{HS}$ stands (with stand as a random variable), and then we tested the effect of fire severity (SEV) using the three paired stands of contrasting fire severity (with pair as a random variable; Proc MIXED [SAS Institute 2000]). The response and/or explanatory variables were occasionally log-transformed to linearize their relationship or to reach homoscedasticity and normality of the residuals. This general design was adjusted to the particular response variable tested as follows. The model testing the proportion of root system in mineral soil also included a cohort effect $(\mathrm{COH}$, i.e., the change in rooting depth from one cohort of trees to the next within the same stand) and its interaction with TSF and SEV. Models testing soil temperature and water table depth also included year of sampling (YR: 2003 vs. 2004) as a repeated measurement, as well as its interaction with TSF and SEV. Models testing each of the physical (bulk density, humification, organic matter content) and chemical ( $\mathrm{pH}$, total $\mathrm{C}$ and $\mathrm{N}, \mathrm{C}: \mathrm{N}, \mathrm{ECEC}$, and base saturation) response variables in soil samples also included the effect of sampling depth, i.e., horizon (HOR: mineral soil, residual organic matter, lower organic horizon, or upper organic horizon [see the earlier paragraphs]) and its interaction with TSF and SEV.

\section{Foliar analysis}

Nutrient concentration in tree foliage represents the net nutrient assimilation and is thus complementary to soil analyses. However, nutrient concentrations in sameage foliage change as stands age (Bormann and Sidle 1990). Accordingly, we sampled foliage in the three pairs of stands that were established after the same fire (1907, 
TABLE 2. Radiocarbon dates and other parameters from the uppermost charcoal horizon found in soils.

\begin{tabular}{lllrl}
\hline \hline Stand & $\begin{array}{c}\text { Laboratory } \\
\text { number }\end{array}$ & \multicolumn{1}{c}{ Dated material } & $\begin{array}{c}\text { Mass } \\
(\mathrm{mg})\end{array}$ & $\begin{array}{c}\text { Age } \\
\left({ }^{14} \mathrm{C} \text { years BP }\right) \dagger\end{array}$ \\
\hline HI-365 & TO-11631 & P. mariana carbonized needles; ericaceous twigs & 26.6 & $300 \pm 50$ \\
HI-710 & TO-11626 & P. mariana carbonized wood & 13.2 & $690 \pm 50$ \\
HI-790 & TO-11627 & P. mariana carbonized cone scales, twigs & 5.5 & $850 \pm 50$ \\
HI-1225 & TO-11628 & P. mariana carbonized cone scales & 2.9 & $1230 \pm 50$ \\
HI-1585 & TO-11629 & P. mariana carbonized cone scales & 4.7 & $1640 \pm 50$ \\
HI-2355 & TO-11630 & P. mariana carbonized cones scales, twigs & 4.2 & $2240 \pm 50$ \\
\hline
\end{tabular}

$\uparrow \mathrm{BP}$ indicates before present (1950); age is given as mean $\pm \mathrm{SD}$.

$\$$ Mean -1 SD to mean +1 SD.

$\S$ When a radiocarbon date intercepted the calibration curve at multiple points, the date showing the highest probability (underlined) was chosen.

1948, 1949) but differed with respect to the severity of the last fire (HS vs. LS; Table 1), thus controlling for stand age. At each site $(n=6)$, current-year (2003) and 1 -year-old (2002) needles were sampled on three trees per height cohort on the south-facing side of the trees. (Stands originating from LS fires show two distinct height cohorts, while those originating from HS fire only have a single one.) Four subsamples were taken on the first $1 \mathrm{~m}$ from the top and were later mixed to account for intratree variability. The samples were analyzed for total $\mathrm{C}$ and $\mathrm{N}$ following the methods outlined above, and for total $\mathrm{P}, \mathrm{K}, \mathrm{Ca}$, and $\mathrm{Mg}$ using acid digestion (Keeney and Nelson 1982) followed by atomic absorption analysis for cations and determination by colorimetry for $\mathrm{P}$ (Lachat Instruments, Milwaukee, Wisconsin, USA). We tested the effects of fire severity (SEV) and cohort $(\mathrm{COH})$ as fixed effects, pair (PAIR) as a random effect, and needle age-class (YR: 2002 vs. 2003) as a repeated measurement (Proc MIXED; SAS Institute 2000).

\section{RESUlts}

\section{Chronosequence validation}

The tree ring dating of postfire cohort trees provided a reliable stand age (i.e., synchronous establishment of rapidly growing trees; see Site selection and dating) in 17 of the 23 stands (Table 1). In the remaining stands, the oldest trees $(>200$ years old) had variable age and slow initial growth, suggesting these trees established under a closed canopy (Appendix A). In these stands, the radiocarbon-dated charcoal indicated considerably older ages, ranging from 365 to 2355 calendar years BP (Table 2). True stand age (i.e., the fire event) likely lies between the minimum age given by tree ring dating and the radiocarbon age, which is possibly older than the fire because of inbuilt age (time since plant death at time of fire, which adds up to the time since fire in the radiocarbon date [Gavin 2001]). The radiocarbon dating of organic matter located immediately above the charcoal horizon in two of the stands gave an intermediate age (Table 1), which is still a minimum age due to SOM turnover (Wang et al. 1996). In this study, we used the charcoal radiocarbon dates because they are probably closer to the real postfire stand age than are the ages of the oldest trees.

Plant macrofossil analysis of the first $5 \mathrm{~cm}$ above the uppermost charcoal layer showed that all stands were dominated by black spruce after fire (Appendix C). Aspen and jack pine, which occasionally dominate after fire in the region, were absent or found in negligible quantity in the early macrofossil record. Macroremains of tamarack, a species which usually grows in poorly drained sites, were also either absent or found in minor proportions (except in the young stand HI-52, which actually had only $6 \%$ of tamarack basal area). Notably, no significant amounts of sedge (Carex spp.) macroremains were found in the early macrofossil record (Appendix D). Shrub species typical of wet conditions such as alder (Alnus rugosa), willow (Salix sp.), and Chamaedaphne calyculata (L.) D. Don., were also absent from the early macrofossil record of most stands, even though some of these species were present in the understory of stands that are today poorly drained (Appendix D). These paleoecological data suggest that after fire, all stands showed similar overstory and understory vegetation, and only differed with respect to soil burn severity. This collection of stands can thus be considered to represent two distinct time series: a chronosequence of stands established after low soil burn severity (LS) vs. after high soil burn severity (HS). Soil burn severity types were not significantly different in terms of soil texture (modified $t$ test; $t_{\mathrm{m}}=1.38, \mathrm{df}=7.26$, $P=0.208)$ and topography $(t$ test; $t=-1.25, \mathrm{df}=21, P=$ 0.2236) (Table 1).

\section{Paludification and stand productivity}

The 2000+ year chronosequence of black spruce stands clearly demonstrated SOM accumulation with time since fire, with a sixfold increase from 50 years to 2350 years after high-severity fires (Fig. 2a). The organic layer was deeper in low-severity stands because they had a residual organic matter (ROM) layer $>5 \mathrm{~cm}$ (Appen$\operatorname{dix}$ B). Associated with the accumulation of an organic layer was a shift in ground vegetation composition, which was dominated by feathermosses (Pleurozium schreberi, Ptilium crista-castrensis, and Hylocomium 
TABLE 2. Extended.

\begin{tabular}{lcc}
\hline \hline $\begin{array}{c}\text { Calibrated } \\
\text { age range } \\
\text { (calendar years) } \neq\end{array}$ & $\begin{array}{c}\text { Calibrated } \\
\text { age, intercepts } \\
\text { (calendar years)§ }\end{array}$ & $\begin{array}{r}\text { Time since } \\
\text { fire (years) }\end{array}$ \\
\hline AD 1515-1650 & AD 1635 & 365 \\
AD 1280-1380 & AD 1290 & 710 \\
AD 1155-1255 & AD 1210 & 790 \\
AD 710-885 & AD 775 & 1225 \\
AD 380-430 & AD 415 & 1585 \\
385-200 BC & 355, 270, 260 BC & 2355 \\
\hline
\end{tabular}

splendens) in relatively young stands, and then was gradually replaced by mosses of the genus Sphagnum in older stands (Fig. 2b,c). The relative abundance of feathermosses was consistently lower in stands that originated from low-severity soil burns, and the increase rate in Sphagnum abundance was also greater in these stands (Fig. 2c).

As the organic layer deepened over time, forest productivity dramatically declined across the chronosequence, as expressed by all stand productivity indices (Fig. 3). The site index (height grown in 50 years of free growth) decreased from 12 to $14 \mathrm{~m}$ in young stands to about 2-4 $\mathrm{m}$ in the oldest stand, with most of this reduction in the first 100-200 years after fire. The productivity index based on radial growth (5-year BAI) also had a strong decline (Fig. 3b). Productivity was lowest in stands that sustained low soil burn severity, but this effect was particularly marked in stand biomass, which showed a time since fire $\times$ severity interaction (Fig. 3c). The disparity in biomass after fires of high vs. low severity eventually disappeared when stand biomass values converged 100-200 years after fire. Productivity decline was also visible between the different tree cohorts within each stand $(\mathrm{COH}$ effect). The cohort effect was not the same for the two soil burn severity classes $(\mathrm{SEV} \times \mathrm{COH}$ interaction); low-severity fires had a more rapid decline in productivity with time (Fig. 3a). Depth of SOM layer was significantly related to the site index at the individual tree level, irrespective of stand age or soil burn severity $\left(R^{2}=0.20, F=32.0, P<0.0001\right.$; Appendix E).

\section{Rooting profiles}

Following high-severity soil burns, trees of the single dominant cohort had a fairly large proportion $(\sim 40 \%)$ of their root system in the mineral soil (Fig. 4). The rooting zone gradually moved upward into the accumulating organic layer, until the dominant cohort of trees had practically no roots in the mineral soil at $\sim 700$ years after fire. Stands that established on the ROM layer left by low-severity fires had $<5 \%$ of their initial root systems imbedded in the mineral soil matrix (Fig. 4, right panels). Thus after low-severity fires, the young (50-year-old) stands have a rooting profile that is comparable to that of 700-year-old stands established after high-severity fires. In stands that had more than one cohort of trees, the codominant (second and third cohorts) trees had a larger proportion of their roots in the organic layer than the dominant cohort (Fig. 4b).

\section{Soil temperature and water table}

Soil temperature at $10 \mathrm{~cm}$ below the surface was significantly affected by stand age (Fig. 5a). Soils gradually became colder in older stands, but the decrease in temperature was not the same in the two years of sampling, probably due to different sampling
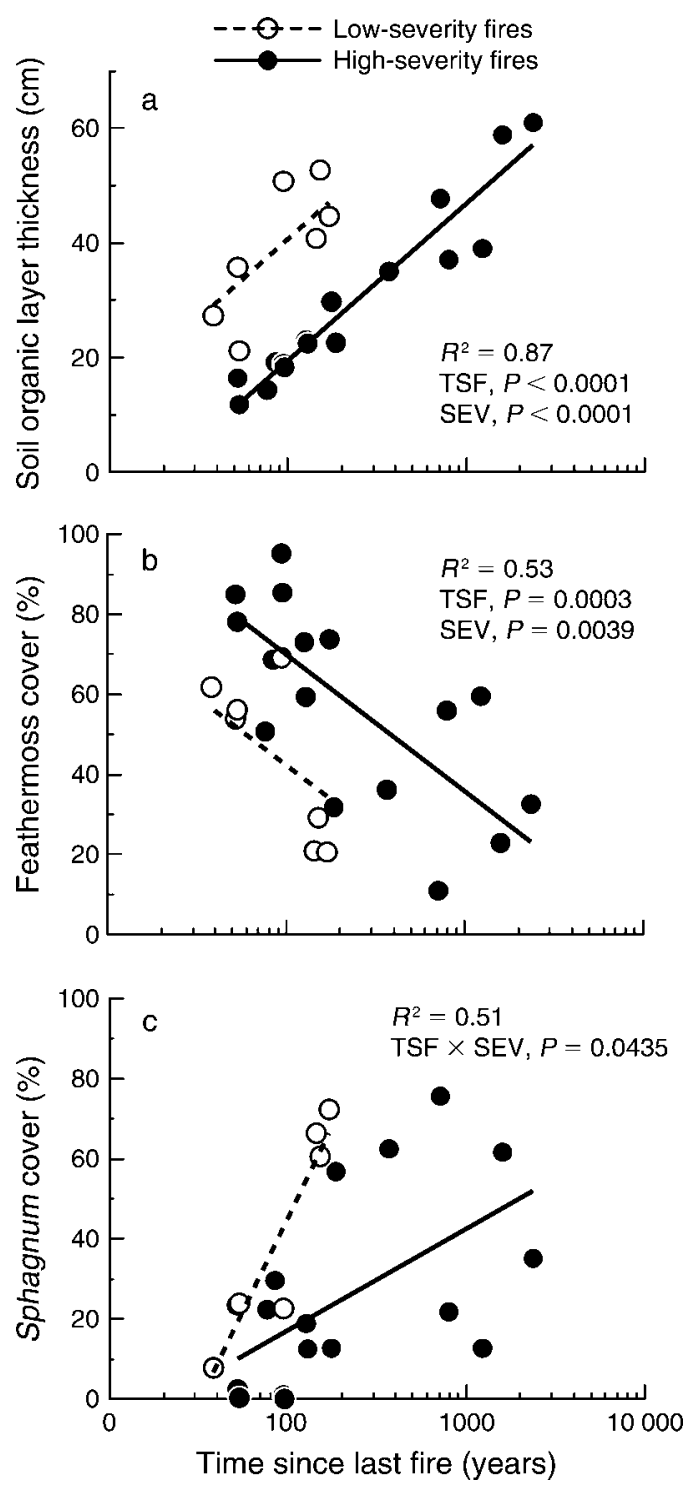

FIg. 2. (a) Accumulation of soil organic matter and change in abundance (percent cover) of (b) feathermosses (Pleurozium schreberi, Ptilium crista-castrensis, and Hylocomium splendens), and of (c) Sphagnum spp. with time since fire (TSF) and severity of the last fire (SEV). In each model, the coefficient of determination (full model) and individual $P$ values (main effects and interaction when present) are shown; main effects are not shown when interactions were significant. 

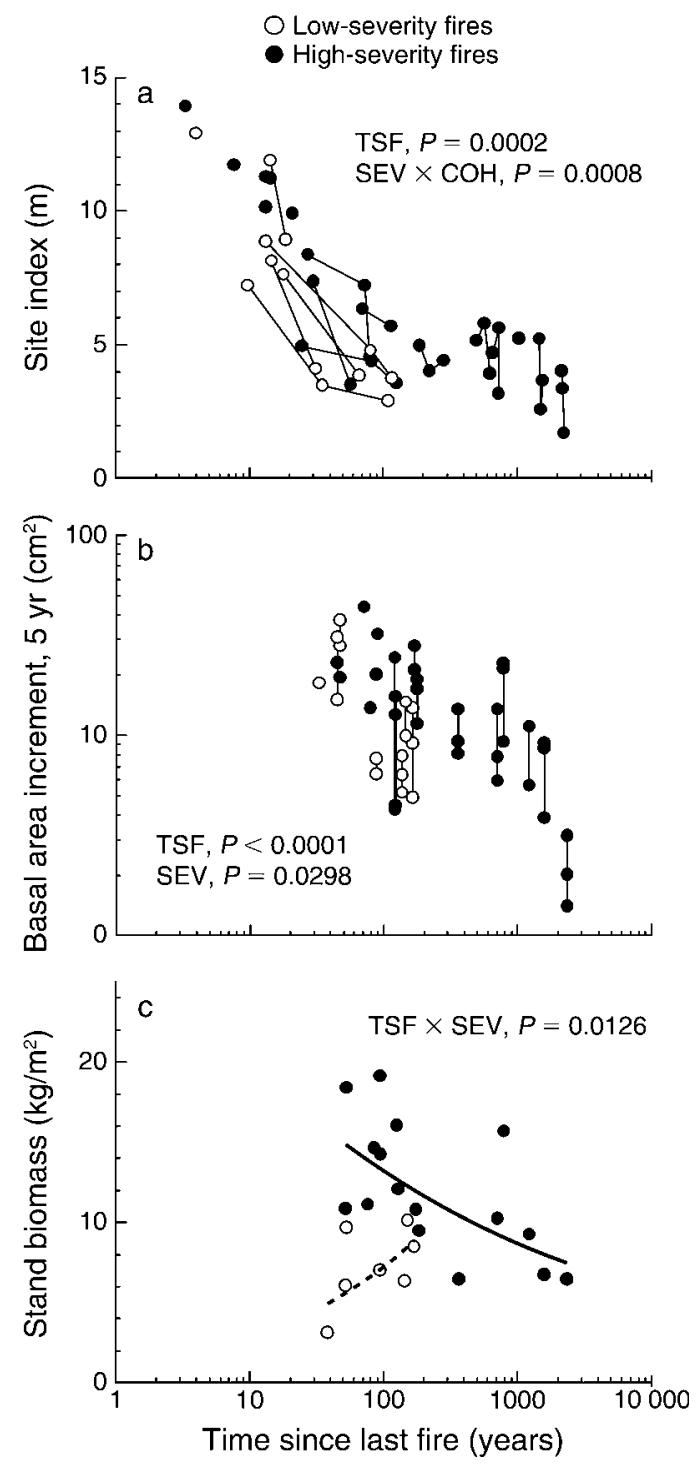

FIG. 3. Changes in forest productivity indices with time and severity of the last fire. In (a) and (b), each circle represents a cohort of trees, and cohorts belonging to the same stand are connected by a line; in (c), each circle represents a stand, with regression lines for stands originating from high- (solid line) and low-severity fires (dashed line). The $P$ values associated with the effect of time since last fire (TSF), fire severity (SEV), and cohorts within the same stand $(\mathrm{COH})$ are shown; main effects are not shown when interactions were significant. Time since fire is the time (a) between fire and growth release, (b) between fire and reference year (1995), and (c) between fire and sampling.

dates. Soil burn severity had no detectable effect on soil temperature. The water table was deep in the young stands established after high-severity fires, so we only recorded its minimum depth in these stands (i.e., $20 \mathrm{~cm}$ and $50 \mathrm{~cm}$ below the mineral soil in 2003 and 2004, respectively). Nonetheless, the elevation of the water table increased with time since high-severity fire, following a similar increase in the organic matter layer
(Fig. 5b). The water table was near the mineral-organic interface in the 365-year-old stand, but was $>20 \mathrm{~cm}$ above that limit in the 700-year-old stand. The water table was $10 \mathrm{~cm}$ above the mineral soil in most young stands originating from low-severity fires. The rise in water table depth with time since fire was also visible in the morphology of the soils. In contrast to all the younger stands, the soil in the 700-year-old stand was strongly gleyed, indicating long-lasting conditions of reduction. This long-term indicator of predominantly waterlogged conditions lends support to our interpretation of our limited record of water table data.

\section{Soil analyses}

Because the organic layer thickens with time since fire, the upper and lower organic horizon samples that were adjacent in young stands became increasingly distant in older stands. The lower organic horizons underwent gradual humification that increased their bulk density with time (Fig. 6a-c). Consequently, the volumetric concentrations of organic matter, carbon, nitrogen, and exchangeable cations increased dramatically in these deeper horizons (Fig. 6d, f, g, i). In the upper horizons, however, a slight decrease in density with time resulted in a reduction of the volumetric concentration of the same elements except ECEC. The $\mathrm{pH}$ increased in both upper and lower (postfire) organic horizons with time since fire, from 4.0 in 50-year-old stands to $\sim 5.0$ in the oldest one. The mineral soil had nutritional properties that were similar (total $\mathrm{N}$ and base saturation) or better (low $\mathrm{C}: \mathrm{N}$, high ECEC) than those found in the organic horizons, particularly compared with the upper horizon (Fig. 6g-j). Overall, the ROM horizon in the young stands established after low-severity fires consistently had physico-chemical properties that were similar to those of the lower organic matter horizon in older highseverity stands.

\section{Foliar analyses}

The concentrations of the major macronutrients nitrogen, phosphorus, and potassium in needles were significantly lower in trees established after low-severity fires (Fig. 7). However, the concentrations of magnesium, calcium, and carbon were not affected by soil burn severity. There was no difference in the needle nutrient content between the first (dominant) and second (codominant) cohorts.

\section{Sphagnum succession}

The overall successional shift from feathermosses to Sphagnum, which was observed in the full chronosequence (Fig. 2), was strongly expressed in the subset of stands (Fig. $8 \mathrm{~b}, \mathrm{c})$. In young ( $\sim 50$-year-old) stands that sustained a high soil burn severity, the feathermoss Pleurozium schreberi dominated the ground cover (80-100\%) while the sphagnum species were absent. The first Sphagnum species to appear were $S$. capillifolium and $S$. russowii at 100-125 years, reaching their 
High-severity fires

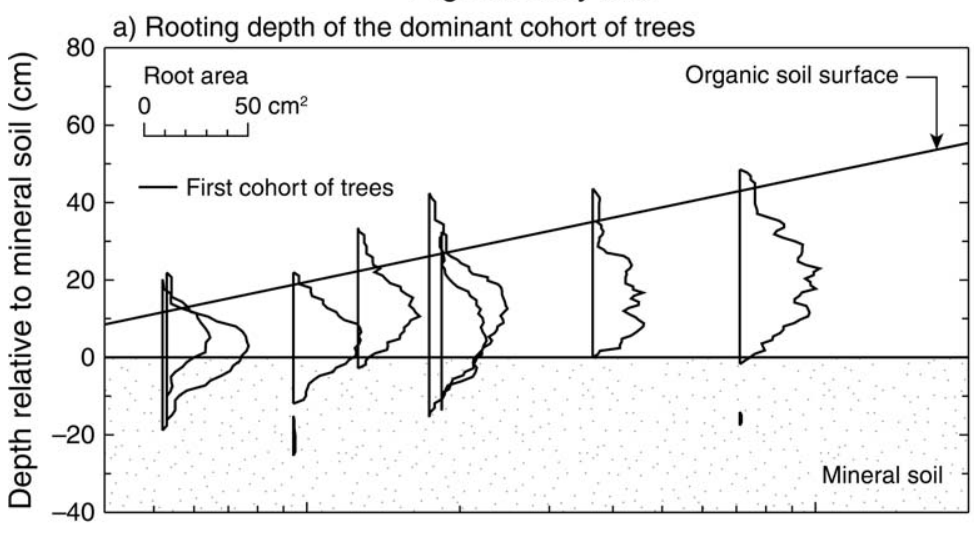

b) Rooting depth of the co-dominant cohorts of trees

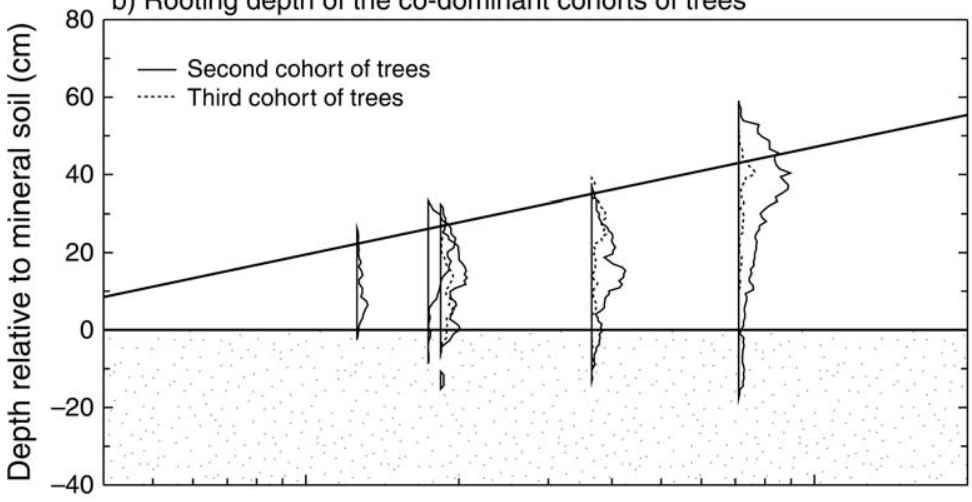

c) Percentage of root system in mineral soil

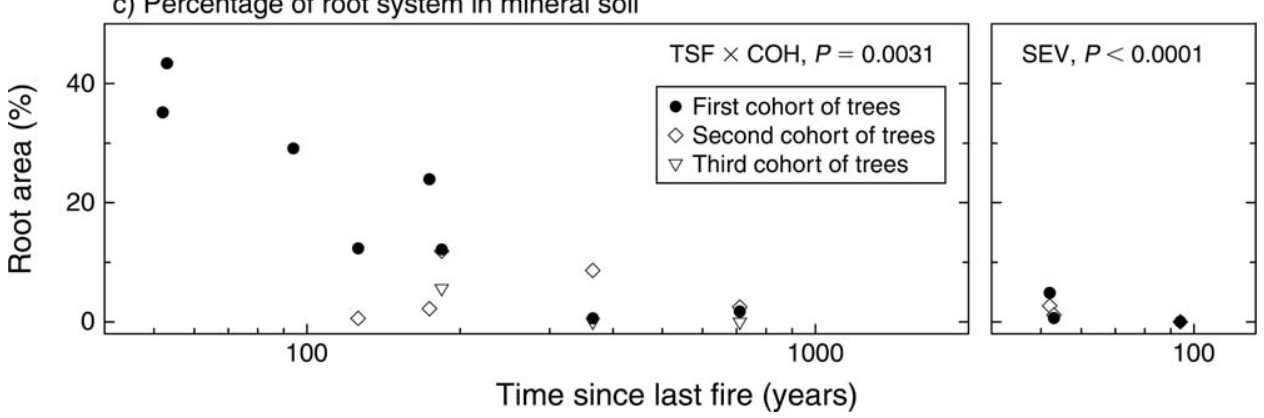

FIG. 4. (a, b) Vertical distribution of black spruce roots (irregular lines to the right of each profile) relative to the position of the mineral soil (patterned area) and organic soil surface (mean surface determined from regression in Fig. 2a) in the eight stands originating from high-severity fires (left-hand panels) and three stands originating from low-severity fires (right-hand panels). Each profile represents a cohort of trees in a stand $(n=3-4$ trees per cohort) and is positioned along the $x$ axis (logarithmic scale) according to the postfire age of the stand (vertical lines to the left of each profile). For clarity, first (dominant) cohorts (a) are shown separately from second and third cohorts (b), when present. In low-severity fires, the residual organic matter (black area and dashed horizontal line) is shown for each stand. (c) Proportion of root area in the mineral soil. Each symbol represents a cohort of trees in a stand. The $P$ values associated with the effects of time since last fire (TSF), cohorts within the same stand $(\mathrm{COH})$, and fire severity (SEV), are shown; main effects are not shown when interactions were significant.

maximum abundance 175 and 365 years after fire, respectively, before showing a reduced cover in the older stands (Fig. 8d, e). At 365 years after fire, Sphagnum girgensohnii and S. rubellum appeared (Fig. 8f, g), although in lower abundance than $S$. russowii, and were replaced in the 700-year-old stand by $S$. magellanicum, S. wulfianum, and S. angustifolium (Fig. 8h-j). Stands that originated from low-severity fires had a relatively high cover of early successional species of Sphagnum, although some late successional species (S. magellanicum and $S$. angustifolium) were also found.

\section{Discussion}

In this study, we used ecological data, paleoecological analyses, and tree ring reconstruction techniques to document paludification and changes in forest produc- 
High-severity fires

a) Soil temperature

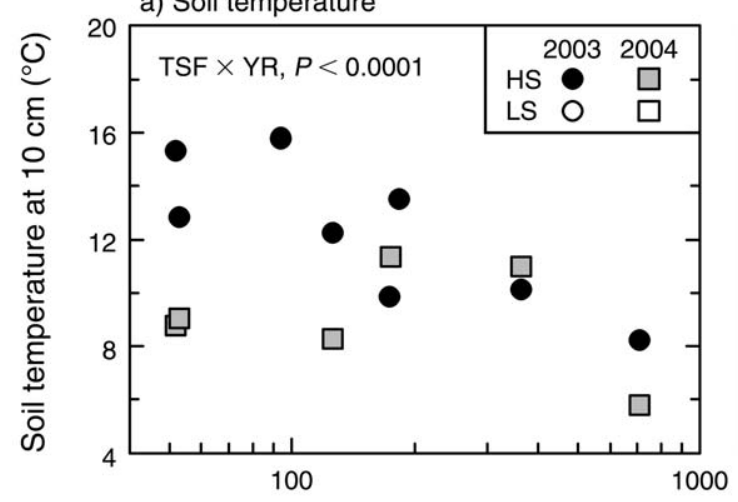

b) Water table depth
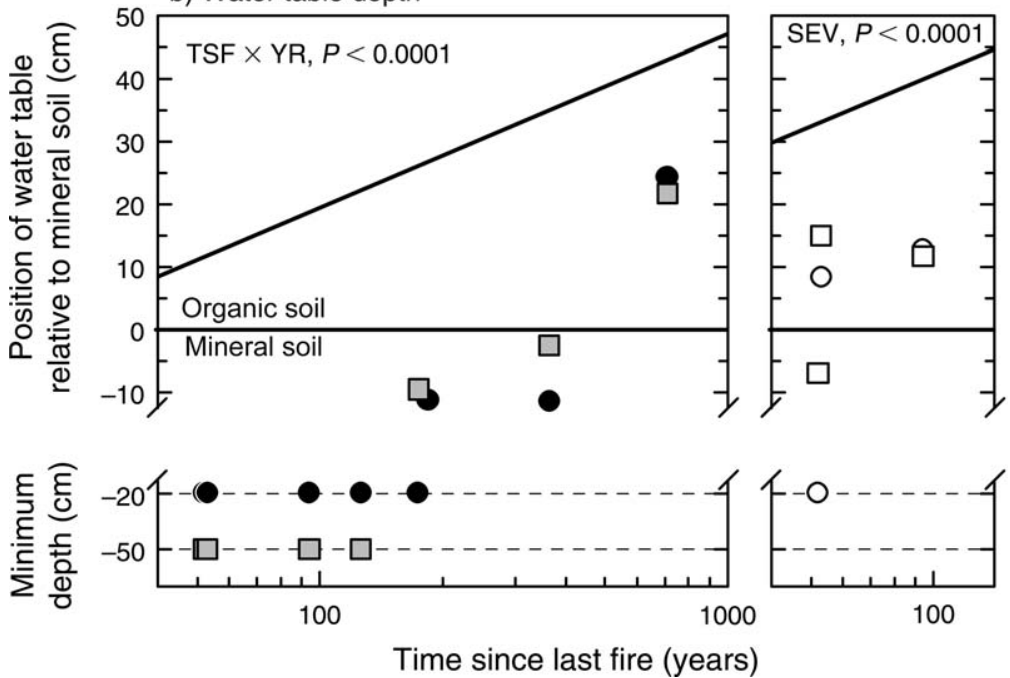

FIG. 5. (a) Relationship between soil temperature at $10 \mathrm{~cm}$ below the surface and stand age (time since fire) for eight black spruce stands originating from high-severity fires (HS, left-hand panels) and three stands originating from low-severity fires (LS, right-hand panels). (b) Depth of the water table relative to the mineral-organic soil interface. The organic soil surface is represented by the oblique line. When the water table was not reached, a minimum depth is shown. In (a) and (b), each symbol represents the mean of 20 measurements taken a single time in 2003 and again in 2004. The $P$ values associated with the effects of time since last fire (TSF), sampling year (YR), and severity of the last fire (SEV) are shown; main effects are not shown when interactions were significant.

tivity occurring in a chronosequence of stands spanning $>2000$ years. Each method clearly demonstrates that successional paludification occurs over time, independent of initial site factors, and causes declines in forest productivity in permafrost-free boreal forests. In this landscape, stand-level productivity of 2350-year-old stands is $50-80 \%$ lower than that of the 50 -year-old stands, depending on the productivity index used. The close agreement between the results obtained from the chronosequence and from the cohort approach reinforces our conclusions.

Both the chronosequence and cohort approaches have inherent strengths that we sought to use to our advantage, and weaknesses that we tried to circumvent. The strength of the chronosequence approach is to enable quantification of change in forest productivity over millennia. It has, however, three main methodological shortcomings. First, the assumption that all stands of a chronosequence experienced the same initial postdisturbance conditions is seldom verified (Pickett 1989). In this study, we verified postdisturbance conditions using paleoecology and charcoal stratigraphy.

None of the sites showed strong paleoecological evidence of wetland vegetation such as presence of alder (Alnus rugosa), willow (Salix spp.), or Chamaedaphne calyculata. Aquatic or sedge peat, which would have indicated minerotrophic conditions associated with fen peatlands developed in wet topographic depressions (edaphic paludification) (Heinselman 1970, Moore and Bellamy 1973, Khury et al. 1993, Payette and Rochefort 2001), was never found in significant amounts at the base of the peat monoliths (early macrofossil record). 

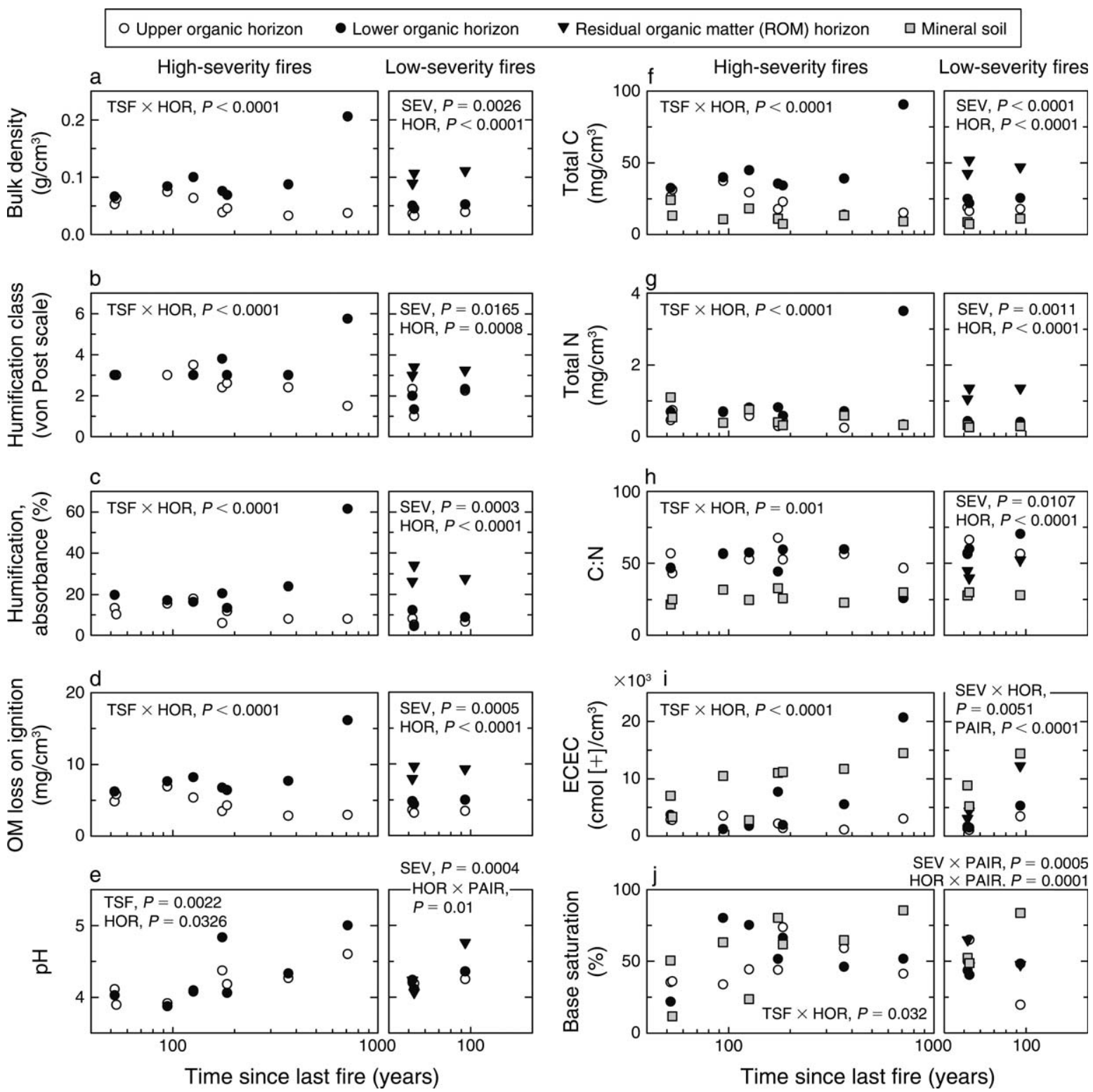

FIG. 6. Change in soil physicochemical characteristics with time since fire in stands showing high $(n=8)$ and low $(n=3)$ soil burn severity. In each stand, soils were sampled in the top $10 \mathrm{~cm}$ of the organic layer (upper organic horizon), in the first $10 \mathrm{~cm}$ above the uppermost charcoal layer (lower organic horizon), and in the mineral horizon; in addition, the residual organic matter was sampled in the low-severity stands. Loss on ignition of organic matter content, total $\mathrm{C}$, total $\mathrm{N}$, and effective cationic exchange capacity (ECEC) are expressed on a volume basis to account for soil density. Humification was measured by (b) class in the von Post method and (c) by the colorimetric method. Each symbol represents five samples. The $P$ values associated with the effects of time since fire (TSF), soil burn severity (SEV), soil horizon (HOR), and pairs of high- and low-severity stands (PAIR) are shown; main effects are not shown when interactions are significant.

Based on these analyses, we conclude that all stands were well-drained postfire black spruce forests. However, charcoal stratigraphy revealed possible differences in burn severity: although many sites had a single charcoal layer located directly above the mineral soil, others showed two or multiple charred horizons overlying welldecomposed organic matter, indicating incomplete combustion of the organic layer (Table 1). We took advantage of this contrasting soil burn severity (Appen- dix B) and used it as an explanatory factor, which proved to be highly significant in most processes involved.

The second problem associated with chronosequence analyses is accuracy of stand age dating. We used a combination of stand reconstruction techniques, tree ring dating, and radiocarbon dating to provide the most reliable stand initiation dates possible. The third problem is a lack of replication between stands of 
2002 needles $\square 2003$ needles
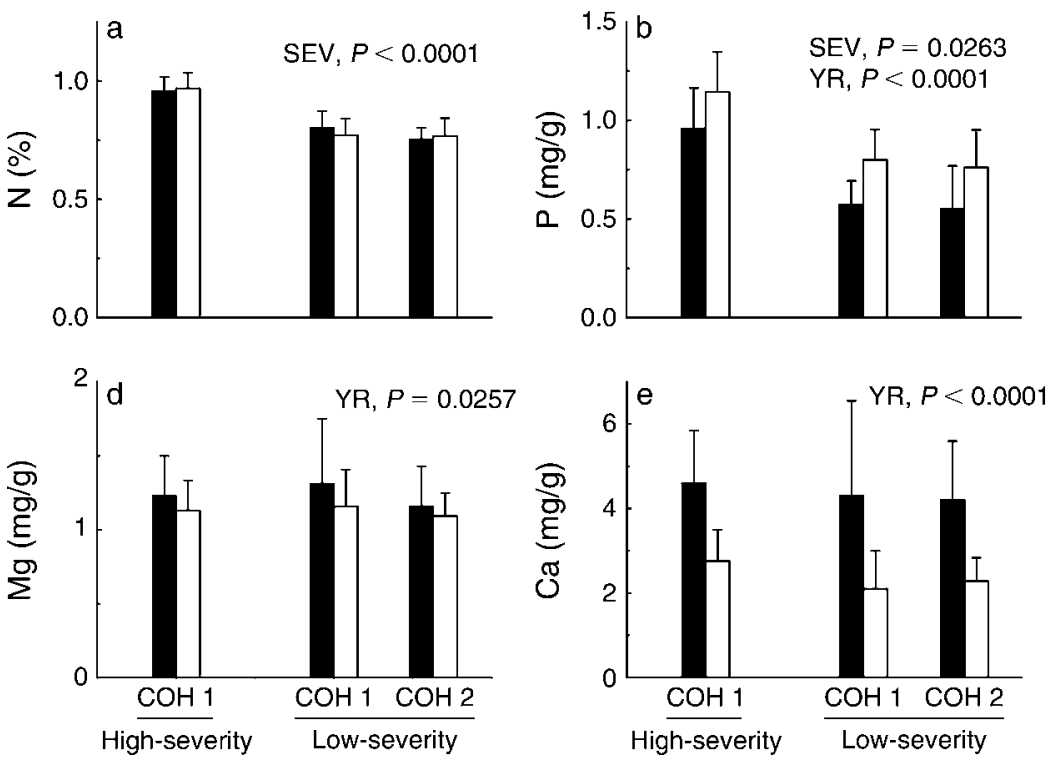
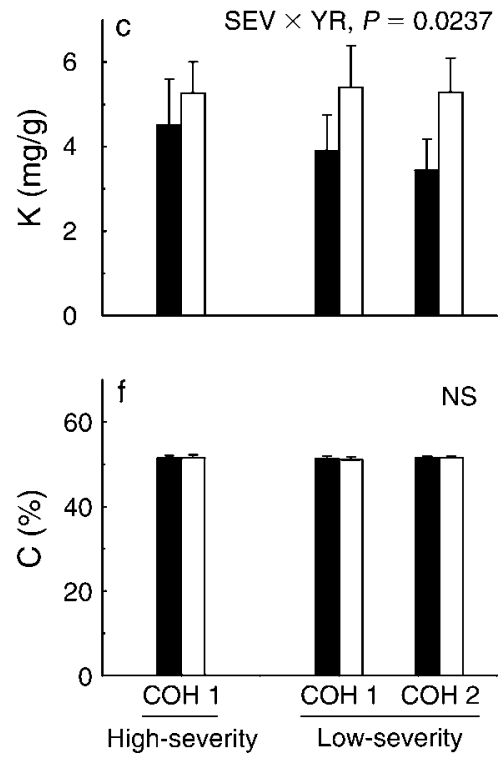

FIG. 7. Concentrations of nutrients and carbon in current-year (2003) and one-year-old (2002) black spruce needles in three pairs of stands (three fire years: 1907, 1948, and 1949) showing contrasting soil burn severity (high vs. low). Both dominant (COH 1) and co-dominant $(\mathrm{COH} 2)$ cohorts were sampled in the low-severity stands, while high-severity stands only showed a single dominant cohort. Each bar represents the mean value of three trees. The $P$ values associated with the effects of sampling year (YR) and soil burn severity (SEV) are shown; main effects are not shown when interactions were significant.

similar age: our chronosequence was composed of 23 sites, many of which were of comparable age except in older age classes. Our chronosequence spanned $>2300$ years, and included forest stands ranging from dense closed-crown stands to open woodlands (Table 1).

The cohort approach, which looks at the productivity of successive cohorts of trees within the same stands, circumvents many problems associated with the chronosequence. In this approach, change in productivity of successive cohorts is assessed within the same stands, thereby controlling for site factors such as soils, drainage, and topography. However, one of the main problems of this approach is that the lower stature of the second and third cohorts exposes them to competition for light from residual trees from the first, taller, cohort. To avoid this, we specifically selected second- and thirdcohort trees that were growing in full light and did not sample them if they were overtopped. This was facilitated by the fact that older stands, which show many cohorts of trees, are also more open (Fig. 3e).

\section{Successional paludification and forest productivity}

In our study area, well-drained postfire black spruce stands originating from high-severity soil burns are typically dominated by the ground moss Pleurozium schreberi, which produces a thick organic layer with time (Lecomte et al. 2005). Our chronosequence data suggest that SOM accumulation is accompanied by a rise of the water table and by a shift in the bryophyte cover from feathermoss to mesic/hummock sphagnum species (Sphagnum capillifolium, S. fuscum), to hydric/hollow sphagnum species ( $S$. angustifolium, $S$. rubellum, $S$. magellanicum) (Andrus et al. 1983). The initial shift from feathermoss to sphagnum species is likely triggered by increased light levels following senescence of the postfire cohort at 100-125 years (Lecomte et al. 2006a), while subsequent succession in Sphagnum probably reflects increases in both light and soil moisture (Fenton and Bergeron 2006). In Alaska, a rise in water table is associated with the presence of permafrost that impedes vertical drainage of water (Viereck 1970). In our permafrost-free soils, the presence of free water in the profile suggests that the low hydraulic conductivity of humified peat gradually disconnects paludified soils from the general lateral flow pattern of the surrounding landscape. In addition, paludification reduces canopy cover, which in turn reduces evapotranspiration and promotes the accumulation of excess water in the profile. In a process that is similar to that found in ombrotrophic peatlands, the water table becomes "suspended" over the general water table level. Thus, the system, once primed by the initial accumulation of Sphagnum, becomes self-perpetuating unless lateral flow is restored through reduction of SOM resulting from soil burning.

As the organic layer thickens and the water table rises, black spruce trees produce adventitious roots (Lieffers and Rothwell 1987), and the rooting zone migrates upward into SOM layers (Ruess et al. 2003). As a result, the root system of these trees shifts from the mineral soil to the organic soil layer (Fig. 4). Following a highseverity soil burn, trees of the first postfire cohort are primarily rooted in the mineral soil, but second-cohort 
- Low-severity fires

High-severity fires
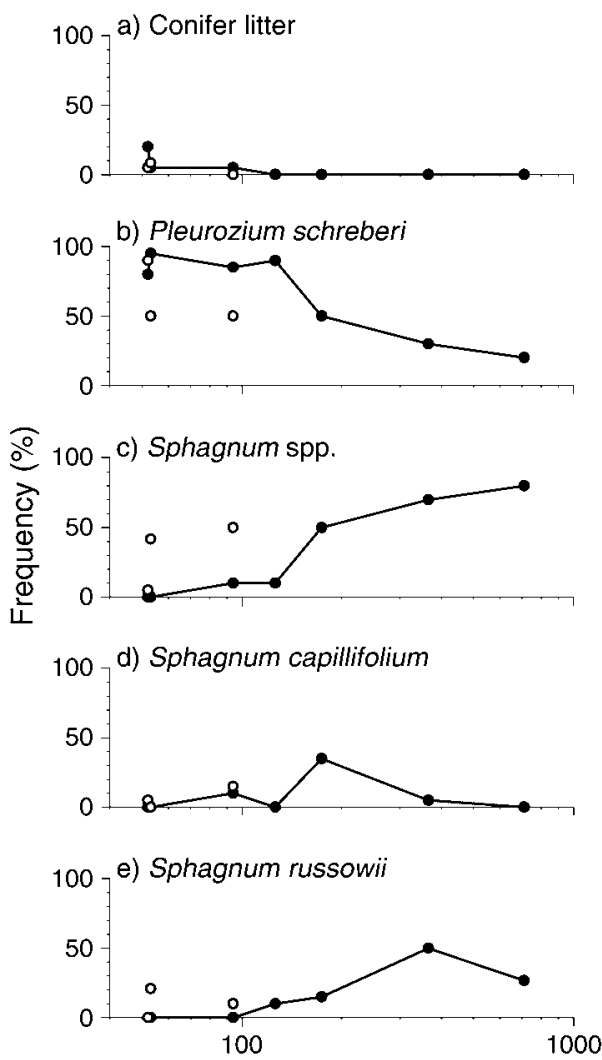

Time since last fire (years)
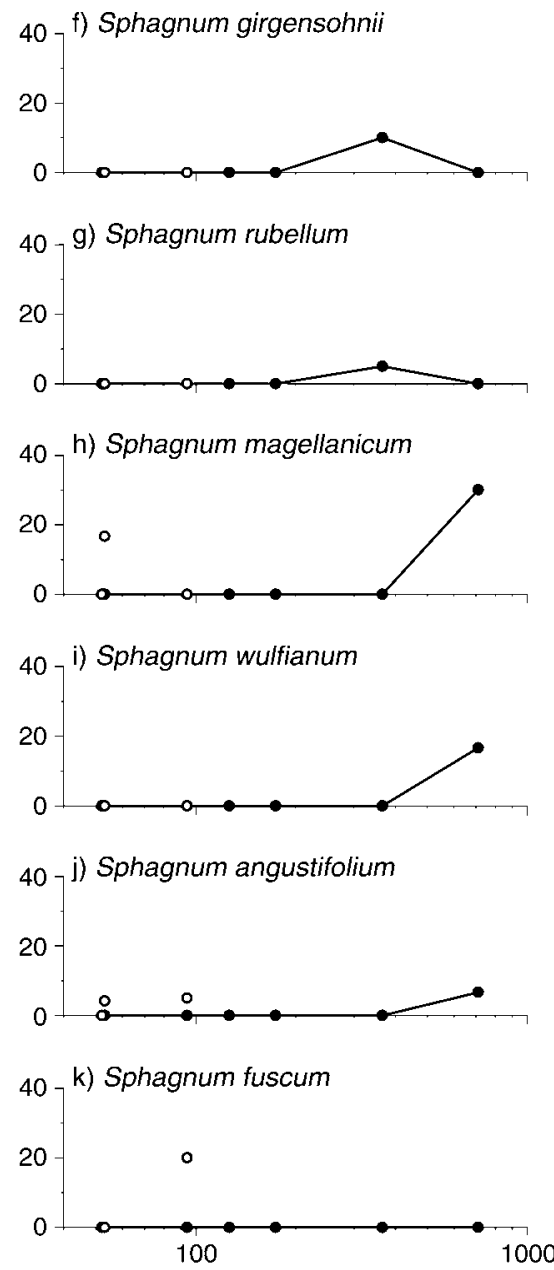

Time since last fire (years)

FIG. 8. Change in litter and bryophyte species frequency with time since fire in stands of high $(n=8)$ and low $(n=3)$ soil burn severity.

trees are almost completely rooted in the organic soil (Fig. 4b). The timing of this change coincides with the observed drop in productivity 100-200 years postfire (Fig. 3), and suggests that an initial productivity decline occurs after the breakup of the postfire cohort (Lecomte et al. 2006a).

The transition from a postfire cohort rooted in the mineral soil to a succeeding cohort rooted in the organic soil could explain the decline in productivity at 100-200 years, because the organic layer is a poor growth medium compared to mineral soil (Fig. 6). Nitrogen, which is the most limiting nutrient in northern soils (Vitousek and Howarth 1991), is eventually sequestered in the deep organic horizons and is not accessible to tree roots in old stands (Heilman 1966). Another consequence of SOM accumulation is a reduction in soil temperature in the rooting zone (Fig. 5). Because of their high porosity compared to mineral soils, organic soils have low thermal diffusivity whether they are dry or wet, and prevent summer warmth from increasing soil temperature (Stathers and Spittlehouse 1990). Most nutrient cycling processes in soils are temperature dependent, and soil temperature has been shown to be a limiting factor in black spruce forest productivity in Alaska (Van Cleve et al. 1981, 1983). Overall, our empirical data confirm the changes in productivity, soil temperature, and water content, as well as in total and available nutrients in the organic and mineral soil, as hypothesized in the theoretical framework of Van Cleve et al. (1983).

\section{The fire regime in a paludified landscape}

Fire is a major disturbance factor that keeps in check the accumulation of SOM across landscapes in black spruce forests. Smoldering combustion has the potential to considerably reduce organic soil biomass (Miyanishi and Johnson 2002), and stands originating from highseverity soil burns generally have high productivity (Fig. 3) (Turner et al. 1997, Johnstone and Chapin 2006). In contrast, low-severity fires leave important 
amounts of residual organic matter (ROM) after the fire, which affects many belowground and aboveground processes in a domino effect resulting in an accelerated succession toward Sphagnum-dominated moss layers (Fig. 2). Low-severity soil burns had a higher Sphagnum to feathermosses ratio, a higher water table, a lower proportion of roots in the mineral soil, a lower concentration of $\mathrm{N}, \mathrm{P}$, and $\mathrm{K}$ in black spruce needles, and a lower stand productivity compared to high-severity burns of the same age. The reduced foliar concentrations of $\mathrm{N}, \mathrm{P}$, and $\mathrm{K}$ in low-severity fires (Fig. 7) and the high concentration of total $\mathrm{N}$ in postfire ROM (Fig. 6g) underscores the importance of high-severity soil burns for nutrient cycling and maintenance of forest productivity (MacLean 1983, Wardle et al. 1997, DeLuca et al. 2002).

Time since fire and soil burn severity therefore both control stand productivity through their joint effect on the thickness of the organic layer. Ultimately, the most direct factor explaining stand productivity decline is a thickening of the organic layer (Appendix E), whether resulting from a long fire-free period following a highseverity fire, or a low soil burn severity in young stands. The two alternative successional pathways (high- and low-severity soil burns) differ initially but eventually converge after 200 years, when productive stands progressively become paludified and low-productivity stands fill in by layering (Fig. 3c) (Lecomte et al. 2006a). In boreal and subalpine ecosystems, disturbance-mediated divergence followed by successional convergence has been shown to affect stand structure (Kashian et al. 2005, Lecomte et al. 2006a), understory vegetation (Lecomte et al. 2005a), and biomass partitioning (Lecomte et al. 2006b).

Low-severity burns promote faster paludification through a positive feedback involving (1) a thicker postfire organic layer, (2) an increased postfire cover of Sphagnum, and (3) a higher water table. In turn, paludification probably increases the probability of low-severity fires by raising the water table. The rise of water table above mineral soil is a critical threshold, although a conservative one, that controls the depth of burn. When stands reach this threshold, on average at $\sim 400$ years after fire (Fig. 5 b), the probability that a fire will consume the entire organic horizon, and thus the probability of reverting to high productivity levels, is low. This positive feedback at the stand scale implies a nonlinear response of paludification to fire frequency and suggests that forest productivity at the landscape scale could be greatly sensitive to slight changes in fire regime.

Because paludification is an ongoing process that can only be reversed by smoldering fires, the proportion of paludified forests over the landscape is fine tuned to the fire regime, which suggests that peat accumulations in the study area would be far more important if fires were absent or at least less frequent (Payette 2001). In contrast, climate per se (precipitation and temperature) does not appear to have been a limiting factor for paludification in the last 2000 years. Our chronosequence spans many important changes in global climate (e.g., the Little Ice Age, $\sim 150-400$ years ago, and the Little Climatic Optimum, $\sim 1000$ years ago), but the rate of organic matter accumulation is fairly regular over time (Fig. 2a). This suggests that in the last 2000 years, peat accumulation has been primarily under strong autogenic control, i.e., driven by succession alone, similar to that found in ombrotrophic bogs (Payette 1988). In contrast, peat reduction is mostly under allogenic control, because the fire regime is controlled by climate. Regional context is also important in explaining the overall prevalence of paludification. The flat topography and compact surficial deposits of the Hudson Bay lowlands are predisposing factors to paludification by reducing the capacity to evacuate soil water.

\section{Climate change, forest management, and carbon sequestration}

The fire cycle in our study area has lengthened markedly in the last centuries, from $\sim 100$ years before 1850 , to $\sim 400$ years since 1920 (Bergeron et al. 2004), and could potentially increase even further in the future (Flannigan et al. 1998, but see Flannigan et al. 2005). A lengthening of the fire cycle will result in an increase in the proportion of paludified forests across the landscape of the Hudson Bay lowlands of northwestern Quebec, accompanied by a reduction in productive forest area. The lengthening in fire cycle is not reflected rapidly in the stand age structure, however, because of the system's inertia. Effects of a reduction in fire frequency on the presence of productive stands probably have a lag time of many decades to centuries. For example, the mature high-productivity stands that are today targeted by the logging industries were established under a climate more conducive to fires.

This study established a strong link between fire and the maintenance of productive stands on the landscape. The question now is if current forest management practices, including suppression of fires and minimization of soil disturbance when logging, enhance paludification or site productivity in the area under study. Logging operations in our study area are similar in effect to low-severity fires because they do not disturb the organic layer (reviewed in Lavoie et al. 2005b). Although fire suppression is believed to have a negligible effect on fire frequency in boreal ecosystems (Bridge et al. 2005), it is very efficient at stopping the smoldering combustion of SOM essential for increased postfire productivity. This suggests that current forestry practices in our study area are enhancing paludification, transforming highproductivity sites to low-productivity ones. Applying general operational rules to this area of high paludification potential may therefore reduce the overall forest productivity of the landscape. 
Even though paludified stands have low aboveground biomass, they actually store a larger amount of carbon than young productive stands because they accumulate large amounts of SOM (Lecomte et al. 2006b) over long periods of time (Lavoie et al. 2005a). The major reduction in regional fire frequency in the last 150 years (Bergeron et al. 2004) has increased the number of old paludified stands across the landscape and has probably resulted in increased sequestration of carbon in the Hudson Bay lowlands, primarily due to SOM accumulation. Although current carbon budget models incorporate the effects of disturbances, they do not consider soil burn severity nor the disproportionate effect of SOM accumulation in forested peatlands, resulting in uncertain estimates of SOM pools (Kurz and Apps 1999, Bhatti et al. 2002a, b, Goodale et al. 2002, Liski et al. 2003). If the Hudson Bay lowlands are indeed undergoing increased paludification, they may act as an important carbon sink and account for a part of the residual terrestrial carbon sink (the "missing sink") that is thought to be located at northern mid-latitudes (Houghton 2003).

\section{ACKNOWLEDGMents}

This study was supported financially by the National Sciences and Engineering Research Council of Canada (NSERC) and Canada Economic Development, Regional Strategic Initiative-Abitibi-Témiscamingue (RSI-Abitibi). We thank our industrial and governmental partners in the Chair in Sustainable Forest Management as well as S. Brassard, P.-O. Côté, R. Gagné, A. Giroux, J.-F. Giroux, J. L. Hooker, and T. Nguyen-Xuan for fieldwork assistance; R. Bourgoin for field equipment design; D. Cyr and H. Asselin for charcoal processing and identification; A. Larouche and H. Asnong (Université de Montréal) for macrofossil analyses of soil monoliths; A. Courcelles and R. Morin (Canadian Forest Service) for soil analyses; G. Ayotte (Herbier Louis-Marie, Université Laval) for Sphagnum identification; and M. BernierCardou and D. Boucher for statistical advice. We thank R. Jandl and an anonymous reviewer for helpful suggestions on this manuscript.

\section{Literature Cited}

Andrus, R. E., D. J. Wagner, and J. E. Titus. 1983. Vertical zonation of Sphagnum mosses along hummock-hollow gradients. Canadian Journal of Botany 61:3128-3139.

Asada, T., B. G. Warner, and A. Banner. 2004. Sphagnum invasion after clear-cutting and excavator mounding in a hypermaritime forest of British Columbia. Canadian Journal of Forest Research 34:1730-1746.

Bergeron, Y., S. Gauthier, M. D. Flannigan, and V. Kafka. 2004. Fire regimes at the transition between mixedwood and coniferous boreal forest in northwestern Quebec. Ecology 85: 1916-1932.

Bhatti, J. S., M. J. Apps, and H. Jiang. 2002a. Influence of nutrients, disturbances and site conditions on carbon stocks along a boreal forest transect in central Canada. Plant and Soil 242:1-14.

Bhatti, J. S., M. J. Apps, and C. Tarnocai. 2002b. Estimates of soil carbon stocks in central Canada using three different approaches. Canadian Journal of Forest Research 32: 805-812.

Bormann, B. T., and R. C. Sidle. 1990. Changes in productivity and distribution of nutrients in a chronosequence at Glacier Bay National Park, Alaska. Journal of Ecology 78:561-578.
Brais, S. 2001. Persistence of soil compaction and effects on seedling growth in northwestern Quebec. Soil Science Society of America Journal 65:1263-1271.

Bridge, S. R. J., K. Miyanishi, and E. A. Johnson. 2005. A critical evaluation of fire suppression effects in the boreal forest of Ontario. Forest Science 51:41-50.

Charron, I., and D. F. Greene. 2002. Post-wildfire seedbeds and tree establishment in the southern mixedwood boreal forest. Canadian Journal of Forest Research 32:1607-1615.

Curtis, R. O. 1964. A stem-analysis approach to site-index curves. Forest Science 10:241-256.

Cyr, D., Y. Bergeron, S. Gauthier, and A. Larouche. 2005. Are the old-growth forests of the Clay Belt part of a fire-regulated mosaic? Canadian Journal of Forest Research 35:65-73.

DeLuca, T. H., M.-C. Nilsson, and O. Zackrisson. 2002. Nitrogen mineralization and phenol accumulation along a fire chronosequence in northern Sweden. Oecologia 133: 206-214.

Dyck, W. J., D. W. Cole, and N. B. Comerford, editors. 1994. Impacts of forest harvesting on long-term site productivity. Chapman and Hall, London, UK.

Environment Canada. 2006. Canadian climate normals 19712000. 〈www.climate.weatheroffice.ec.gc.ca〉

Fenton, N., and Y. Bergeron. 2006. Facilitative succession in a boreal bryophyte community driven by changes in available moisture and light. Journal of Vegetation Science 17:65-76.

Fenton, N., N. Lecomte, S. Légaré, and Y. Bergeron. 2005. Paludification in black spruce (Picea mariana) forests of eastern Canada: potential factors and management implications. Forest Ecology and Management 213:151-159.

Flannigan, M. D., Y. Bergeron, O. Engelmark, and B. M. Wotton. 1998. Future wildfire in circumboreal forests in relation to global warming. Journal of Vegetation Science 9: 469-476.

Flannigan, M. D., K. A. Logan, B. D. Amiro, W. R. Skinner, and B. J. Stocks. 2005. Future area burned in Canada. Climatic Change 72:1-16.

Foster, D. R. 1985. Vegetation development following fire in Picea mariana (black spruce)-Pleurozium forests of southeastern Labrador, Canada. Journal of Ecology 73:517-534.

Gauthier, S., L. De Grandpré, and Y. Bergeron. 2000. Differences in forest composition in two boreal forest ecoregions of Quebec. Journal of Vegetation Science 11:781-790.

Gavin, D. G. 2001. Estimation of inbuilt age in radiocarbon ages of soil charcoal for fire history studies. Radiocarbon 43: $27-44$.

Goodale, C. L., et al. 2002. Forest carbon sinks in the Northern Hemisphere. Ecological Applications 12:891-899.

Gower, S. T., R. E. McMurtrie, and D. Murty. 1996. Aboveground net primary production decline with stand age: potential causes. Trends in Ecology and Evolution 11: 378-382.

Gray, D. R., J. Régnière, and B. Boulet. 2000. Analysis and use of historical patterns of spruce budworm defoliation to forecast outbreak patterns in Quebec. Forest Ecology and Management 127:217-231.

Harper, K. A., C. Boudreault, L. De Grandpré, P. Drapeau, S. Gauthier, and Y. Bergeron. 2003. Structure, composition, and diversity of old-growth black spruce boreal forest of the Clay Belt region in Quebec and Ontario. Environmental Review 11:S79-S98.

Heilman, P. E. 1966. Change in distribution and availability of nitrogen with forest succession on north slopes in interior Alaska. Ecology 47:825-831.

Heinselman, M. L. 1963. Forest sites, bog processes, and peatland types in the Glacial Lake Agassiz region, Minnesota. Ecological Monographs 33:327-374.

Heinselman, M. L. 1970. Landscape evolution, peatland types, and the environment in the Lake Agassiz Peatlands Natural Area, Minnesota. Ecological Monographs 40:235-261. 
Hendershot, W. H., H. Lalande, and M. Duquette. 1993. Ion exchange and exchangeable cations. Pages 167-176 in M. R. Carter, editor. Soil sampling and methods of analysis. Lewis, Boca Raton, Florida, USA.

Holmes, R. L. 1983. Computer-assisted quality control in treering dating and measurement. Tree-Ring Bulletin 44:69-75.

Houghton, R. A. 2003. Why are estimates of the terrestrial carbon balance so different? Global Change Biology 9: $500-509$.

Johnstone, J. F., and F. S. Chapin, III. 2006. Effects of soil burn severity on post-fire tree recruitment in boreal forest. Ecosystems 9:14-31.

Kashian, D., M. G. Turner, W. H. Romme, and C. G. Lorimer. 2005. Variability and convergence in stand structural development on a fire-mediated subalpine landscape. Ecology $86: 643-654$.

Keeney, D. R., and D. W. Nelson. 1982. Nitrogen - inorganic forms. Pages 643-698 in A. L. Page, R. H. Miller, and D. R. Keeney, editors. Methods of soil analysis. Part 2. Chemical and microbiological properties. Agronomy Monograph Number 9. Second edition. American Society of Agronomy-Soil Science Society of America, Madison, Wisconsin, USA.

Khury, P., B. Nicholson, L. D. Gignac, D. H. Vitt, and S. E. Bayley. 1993. Development of Sphagnum-dominated peatlands in boreal continental Canada. Canadian Journal of Botany 71:10-22.

Kurz, W. A., and M. J. Apps. 1999. A 70-year retrospective analysis of carbon fluxes in the Canadian forest sector. Ecological Applications 9:526-547.

Lavoie, M., D. Paré, and Y. Bergeron. 2005a. Impact of global change and forest management on carbon sequestration in northern forested peatlands. Environmental Review 13: 1999-2040.

Lavoie, M., D. Paré, N. Fenton, A. Groot, and K. Taylor. 2005b. Paludification and management of forested peatlands in Canada: a literature review. Environmental Review 13: 21-50.

LeBlanc, D. C. 1990. Relationships between breast-height and whole-stem growth indices for red spruce on Whiteface Mountain, New York. Canadian Journal of Forest Research 20:1399-1407.

Lecomte, N., M. Simard, and Y. Bergeron. 2006a. Effects of fire severity and initial tree composition on stand structural development in the coniferous boreal forest of northwestern Québec, Canada. Ecoscience 13:152-163.

Lecomte, N., M. Simard, Y. Bergeron, A. Larouche, H. Asnong, and P. J. H. Richard. 2005. Effects of fire severity and initial tree composition on understorey vegetation dynamics in a boreal landscape inferred from chronosequence and paleoecological data. Journal of Vegetation Science 16:665-674.

Lecomte, N., M. Simard, N. Fenton, and Y. Bergeron. $2006 b$. Fire severity and long-term ecosystem biomass dynamics in coniferous boreal forests of eastern Canada. Ecosystems 9: $1215-1230$.

Lieffers, V. J., and R. L. Rothwell. 1987. Rooting of peatland black spruce and tamarack in relation to depth of water table. Canadian Journal of Botany 65:817-821.

Liski, J., A. V. Korotkov, C. F. L. Prins, T. Karjalainen, D. G. Victor, and P. E. Kauppi. 2003. Increased carbon sink in temperate and boreal forests. Climatic Change 61:89-99.

MacLean, D. A. 1983. Fire and nutrient cycling. Pages 111-132 in R. W. Wein and D. A. MacLean, editors. The role of fire in northern circumpolar ecosystems. John Wiley and Sons, Chichester, UK.

McKeague, J. A. 1976. Manual on soil sampling and methods of analysis. Canadian Society of Soil Sciences, Ottawa, Ontario, Canada.

Miyanishi, K., and E. A. Johnson. 2002. Process and patterns of duff consumption in the mixedwood boreal forest. Canadian Journal of Forest Research 32:1285-1295.
Moore, P. D., and D. J. Bellamy. 1973. Peatlands. Elek Science, London, UK.

Murty, D., R. E. McMurtrie, and M. G. Ryan. 1996. Declining forest productivity in aging forest stands: a modeling analysis of alternative hypotheses. Tree Physiology 16:187-200.

Ouellet, D. 1983. Biomass prediction equations for black spruce in Quebec. Information Report LAU-X-60E. Canadian Forest Service, Laurentian Forestry Centre, Sainte-Foy, Quebec, Canada.

Panshin, A. J., and C. de Zeeuw. 1980. Textbook of wood technology. Fourth edition. McGraw-Hill, New York, New York, USA.

Parent, L. E., and J. Caron. 1993. Physical properties of organic soils. Pages 441-471 in M. R. Carter, editor. Soil sampling and methods of analysis. Lewis, Boca Raton, Florida, USA.

Payette, S. 1988. Late-Holocene development of subarctic ombrotrophic peatlands: allogenic and autogenic succession. Ecology 69:516-531.

Payette, S. 2001. La stratigraphie. Pages 345-370 in S. Payette and L. Rochefort, editors. Écologie des tourbières du Québec-Labrador. Les Presses de l'Université Laval, Québec, Canada.

Payette, S., and L. Rochefort, editors. 2001. Écologie des tourbières du Québec-Labrador. Les Presses de l'Université Laval, Québec, Canada.

Pickett, S. T. A. 1989. Space-for-time substitution as an alternative to long-term studies. Pages 110-135 in G. E. Likens, editor. Long-term studies in ecology: approaches and alternatives. Springer-Verlag, New York, New York, USA.

Prescott, C. E., D. G. Maynard, and R. Laiho. 2000. Humus in northern forests: friend or foe? Forest Ecology and Management 133:23-36.

Robitaille, A., and J.-P. Saucier. 1998. Paysages régionaux du Québec méridional. Les publications du Québec, Québec, Canada.

Ruess, R. W., R. L. Hendrick, A. J. Burton, K. S. Pregitzer, B. Sveinbjörnssön, M. F. Allen, and G. E. Maurer. 2003. Coupling fine root dynamics with ecosystem carbon cycling in black spruce forests of interior Alaska. Ecological Monographs 73:643-662.

Ryan, M. G., D. Binkley, and J. H. Fownes. 1997. Age-related decline in forest productivity: pattern and process. Advances in Ecological Research 27:213-262.

Ryan, M. G., D. Binkley, J. H. Fownes, C. P. Giardina, and R. S. Senock. 2004. An experimental test of the causes of forest growth decline with stand age. Ecological Monographs 74:393-414.

SAS Institute. 2000. SAS/STAT user's guide, version 8.2. SAS Publishing, Cary, North Carolina, USA.

Smithwick, E. A. H., M. C. Mack, M. G. Turner, F. S. Chapin, III, J. Zhu, and T. C. Balser. 2005. Postfire soil N cycling in northern conifer forests affected by severe, stand-replacing wildfires. Ecosystems 8:163-181.

Soil Classification Working Group. 1998. The Canadian system of soil classification. Third edition. Agriculture and AgriFood Canada, Ottawa, Ontario, Canada.

Stathers, R. J., and D. L. Spittlehouse. 1990. Forest soil temperature manual. FRDA report 130. Forestry Canada and BC Ministry of Forests, Victoria, British Columbia, Canada.

Stuiver, M., and P. J. Reimer. 1993. Extended ${ }^{14} \mathrm{C}$ database and revised CALIB radiocarbon program. Radiocarbon 35: 215-230.

Swanson, D. K., B. Lacelle, and C. Tarnocai. 2000. Temperature and the boreal-subarctic maximum in soil organic carbon. Géographie Physique et Quaternaire 54:157-167.

Turner, M. G., W. H. Romme, R. H. Gardner, and W. W. Hargrove. 1997. Effects of fire size and pattern on early succession in Yellowstone National Park. Ecological Monographs 67:411-433. 
Van Cleve, K., R. J. Barney, and R. Schlentner. 1981. Evidence of temperature control of production and nutrient cycling in two interior Alaska black spruce ecosystems. Canadian Journal of Forest Research 11:258-273.

Van Cleve, K., F. S. Chapin, III, C. T. Dyrness, and L. A. Viereck. 1991. Element cycling in taiga forests: state-factor control. BioScience 41:78-88.

Van Cleve, K., C. T. Dyrness, L. A. Viereck, J. Fox, F. S. Chapin, III, and W. C. Oechel. 1983. Taiga ecosystems in interior Alaska. BioScience 33:39-44.

Van Cleve, K., and L. A. Viereck. 1981. Forest succession in relation to nutrient cycling in the boreal forest of Alaska. Pages 185-211 in D. C. West, H. H. Shugart, and D. B. Botkin, editors. Forest succession: concepts and application. Springer-Verlag, New York, New York, USA.

Veillette, J. J. 1994. Evolution and paleohydrology of glacial lakes Barlow and Ojibway. Quaternary Science Reviews 13: 945-971.

Viereck, L. A. 1970. Forest succession and soil development adjacent to the Chena River in interior Alaska. Arctic and Alpine Research 2:1-26.
Viereck, L. A. 1983. The effects of fire in black spruce ecosystems of Alaska and northern Canada. Pages 201-220 in $\mathrm{R}$. W. Wein and D. A. MacLean, editors. The role of fire in northern circumpolar ecosystems. John Wiley and Sons, Chichester, UK.

Vitousek, P. M., and R. W. Howarth. 1991. Nitrogen limitation on land and in the sea: how can it occur? Biogeochemistry 13: $87-115$.

Wang, Y., R. Amundson, and S. E. Trumbore. 1996. Radiocarbon dating of soil organic matter. Quaternary Research 45:282-288.

Wardle, D. A., G. Hörnberg, O. Zackrisson, M. KalelaBrundin, and D. A. Coomes. 2003. Long-term effects of wildfire on ecosystem properties across an island area gradient. Science 300:972-975.

Wardle, D. A., O. Zackrisson, G. Hörnberg, and C. Gallet. 1997. The influence of island area on ecosystem properties. Science 277:1296-1299.

Zaehle, S., S. Sitch, I. C. Prentice, J. Liski, W. Cramer, M. Erhard, T. Hickler, and B. Smith. 2006. The importance of age-related decline in forest NPP for modeling regional carbon balances. Ecological Applications 16:1555-1574.

\section{APPENDIX A}

Age structure of the chronosequence stands and a discussion on the determination of time since fire (Ecological Archives A017069-A1).

\section{APPENDIX B}

Frequency distribution of residual organic matter (ROM) layer thickness in forest soils (Ecological Archives A017-069-A2).

\section{APPENDIX C}

Abundance of tree species in the macrofossil record and in vegetation surveys (Ecological Archives A017-069-A3).

\section{APPENDIX D}

Abundance of selected understory plants species in the macrofossil record and in vegetation surveys (Ecological Archives A017069-A4).

\section{APPENDIX E}

Relationship between soil organic layer thickness and site index for individual trees (Ecological Archives A017-069-A5). 